American University Washington College of Law

Digital Commons @ American University Washington College of

Law

Articles in Law Reviews \& Other Academic Journals

Scholarship \& Research

1997

The Factional Foundations of Competition Policy in America

1888-1992

James May

Follow this and additional works at: https://digitalcommons.wcl.american.edu/facsch_lawrev

Part of the Antitrust and Trade Regulation Commons, Law and Economics Commons, and the Legal History Commons 


\section{The factional foundations of Competition Policy in America 1888-1992}

BY JAMES MAY*

Professor Rudolph J.R. Peritz's remarkable new book, Competition Policy in America 1888-1992,' innovatively examines the interrelated development of a series of highly important fields of American law over the last 100 years. The book provocatively examines the way in which key changes not only in antitrust law, but also in labor law, corporate law, and First Amendment jurisprudence all have reflected and helped to shape typically embattled basic beliefs about competition, property rights, efficiency, liberty, and equality in the United States.

The book's virtues are by no means limited to the specialized insights it offers with regard to each of the major areas it examines. Professor Peritz ties each of the legal areas he explores to larger changes over time in American economic life, culture, politics, and ideology. At the same time, he highlights the need to consider the parallels, contrasts, and interconnections among the

* Professor of Law, American University, Washington, DC.

1 Rudolph J.R. Peritz, Competition Policy in America 1888-1992: HISTORY, RHETORIC, LAW (1996).

() 1997 by Federal Legal Publications, Inc. 
developments that occurred within each of these diverse fields, fields that typically have been explored too much in isolation from one another. The particular approach that Professor Peritz takes in this multifield examination is creative and, indeed, unique among scholarly examinations of the last century of competition law in America. His approach constantly challenges readers to rethink well-established understandings of American legal and cultural evolution and to reconsider the implications of that evolution for practice and possibilities in our own time.

What Professor Peritz offers us, specifically, is a "rhetorical history of competition policy"2 broadly understood. In doing so, he connects his study in at least a general way not only to the work of Michel Foucault, but also, for example, to the extensive recent scholarship exploring the nature and impact of such "rhetorics" or "languages of discourse" as classical republicanism and liberalism in late 18th- and 19th-century America. ${ }^{3}$

Professor Peritz's book grows out of but goes very substantially beyond his earlier articles exploring competition and property rhetorics in antitrust law. ${ }^{4}$ In those articles, Peritz sought to challenge more narrowly focused understandings of antitrust tradition and logic that had become prevailing orthodoxy by the late 1980s. In particular, he disputed judicial, enforcement, and scholarly beliefs that the sole concern of antitrust law is to preserve marketplace competition. ${ }^{5}$ Peritz took issue with Chicago school

2 Id. at 8.

3 See id. at 8 n.7.

4 Rudolph J. Peritz, A Counter-History of Antitrust Law, 1990 DukE L.J. 263 [hereinafter Peritz, Counter-History]; Rudolph J. Peritz, A Geneology of Vertical Restraints Doctrine, 40 HASTINGS L.J. 511 (1989) [hereinafter Peritz, Geneology]; Rudolph J. Peritz, The Predicament of Antitrust Jurisprudence: Economics and the Monopolization of Price Discrimination Argument, 1984 Duke L.J. 1205; Rudolph J. Peritz, The "Rule of Reason" in Antitrust Law: Property Logic in Restraint of Competition, 40 Hasrings L.J. 285 (1989) [hereinafter Peritz, "Rule of Reason"].

5 See Peritz, Counter-History, supra note 4; Peritz, Geneology, supra note 4; Peritz, "Rule of Reason," supra note 4. 
efforts to marginalize earlier legislative and judicial expressions of concern for small business welfare. He especially challenged the Chicago school attempt to oust such "property" concerns from the antitrust field as a claimed necessary step to promote the coherence and intellectual respectability of antitrust law. ${ }^{6}$ In these prior articles, Peritz focused substantially, but by no means exclusively, on early antitrust history. He sought to demonstrate that the historical interpretations he challenged told only half the story of what antitrust law has been about since its beginnings. ${ }^{7}$

Professor Peritz begins his new, much more sweeping study by noting how pervasively in America images of "free competition" influence social theories, activity, and public debate in such diverse realms as business, politics, sports, and public speech. $\mathrm{He}$ immediately points out, however, the fundamental ambiguity that inheres in this key concept. He emphasizes that persistent struggles have been waged over which threats to free competition should be emphasized: those posed by government or those posed by private economic power. Peritz stresses that an emphasis on each of these threats, respectively, has implicated a related commitment to one of a pair of basic American ideals. While belief in competition freed from government regulation "has supported a commitment to individual liberty," 8 belief in competition freed from private economic power "has involved a commitment to rough equality." Competition policy over time, however, he relates, has not been informed solely by "these twin rhetorics of free competition" reflecting commitments to liberty and equality, respectively. It also has been informed, he notes, by private property rights concerns and conceptions. ${ }^{10}$

Peritz argues that while the twin rhetorics of free competition are not necessarily contradictory, they repeatedly have been in

6 See, e.g., Peritz, Counter-History, supra note 4, at 265, 268.

7 See, e.g., Peritz, "Rule of Reason," supra note 4, at 287, 288.

8 PERITZ, supra note 1 , at 3.

9 Id.

10 See id. at $3-4$. 
tension with one another over the course of the last hundred years. Similarly, Peritz believes that recurring friction, but not necessarily antinomy, also has characterized the relationship "between competition policy and private property rights." 11 Peritz seeks to understand better the evolution of these patterns and relationships within the variety of interrelated fields of law he explores, as these have played out since the late 19th century. As he describes it, his exploration of competition policy in America

approaches the subject matter as rhetorical confrontations between factions engaged in public discourse, factions informed by their own distinctive clusters of ethical commitments and logical connections. Together, rivalrous rhetorics of free competition have expressed the ethical and logical grounds, the unstable and sometimes explosive foundation, for American political economy over the last twelve decades or so. ${ }^{12}$

Peritz stresses that general rhetorics not only shape but are shaped by material circumstances. He also emphasizes that such rhetorics do not mechanistically or inexorably determine the specific positions and outcomes they affect. Indeed, he notes that general rhetorical frameworks, or "structures of thought and belief,"13 attain longevity in large part because of their adaptability. ${ }^{14}$

Nevertheless, Peritz argues that everyone relies on general structures of thought to understand the world around them. ${ }^{15}$ As a consequence, he contends, an historical analysis of influential general rhetorics can help illuminate not only what persons and factions in the past intended but the limits of what would have been imaginable to them. ${ }^{16}$ More specifically, Peritz argues that an historical analysis of the interaction of rivalrous general rhetorics
1 See id. at 4.
12 See id.
13 Id.
14 Id.
15 Id.
$16 \quad I d$. at 5 . 
can help to make it clear that American competition policy has not simply progressed steadily upward since the 1890 s through the continual refinement of careful, consensus reasoning. Instead, he urges, a history of prevailing rhetoric demonstrates that competition policy has been "the outcome of struggles and confrontations, both among political or ideological factions and, at another level, between utopian aspirations and material conditions." 17 Clarification that this has been the dynamic behind the evolution of current ideas about competition, property rights, efficiency, liberty, and equality, he argues, beneficially reveals such ideas to be "contestable social and political choices," rather than "products of (super)natural, historical, economic, or logical necessity."18 Finally, Peritz notes that such a new examination of the ideological struggles waged over competition policy in the past can produce

a re-collection of the forgotten voices, rejected dissenting opinions, declined positions, and disparaged theories that were part of those debates. I want to throw open an archive of counterpolicies and counterarguments, to recall the conflicts engaged in and the alternative views so fiercely held, views whose appeal continues to inspire debate about political economy. ${ }^{19}$

Competition Policy in America 1888-1992 presents a fresh, intensive, and densely packed new examination of the record of competition policy since the late 19th century "formative era" of American antitrust law. It thoughtfully reconceptualizes the scope of competition policy to focus on areas of legal thought and development going well beyond antitrust law itself. At a minimum, this product of formidable effort by Professor Peritz constitutes a valuable, pointed call for us to think in new ways, both about the totality of American competition policy experience as it has developed to date and about the insights and implications this history may present for current policy thinking and action. The book is likely to spark considerable new scholarly dialog and
17 Id.
$18 \quad I d$. at 8.
19 Id. at 5. 
debate on the specific issues that Professor Peritz raises, not only among antitrust scholars, but also among such scholars and scholars whose primary focus is on one or more of the various other substantive fields that Peritz addresses.

Given its highly ambitious scope and its original interpretative framework, Competition Policy in America 1888-1992 inevitably raises more important issues than can be discussed exhaustively or resolved definitively within a single volume. Peritz's own emphases and analyses suggest intriguing possibilities while still leaving room for considerable further reflection and debate on a wide range of issues that his book provocatively poses in a new way.

This review article focuses on the central theme of Peritz's book: that competition policy in America from the 1880s to the 1990s has evolved through the continued interplay between two great opposing rhetorical factions. In examining this core thesis, this article concentrates on the first third of Peritz's wide-ranging study. This portion of his work offers a new interpretation of the legislative, judicial, and theoretical developments leading up to the transformation of competition policy that accompanied the New Deal. These initial chapters address the passage of the Sherman Act, the Court's jurisprudence from 1890 to the early 1930s, and the evolution of the general theoretical approaches to competition policy that rose to prominence during those decades. Peritz's discussion in these early chapters provides an important basis for understanding much of the rest of his work. It also provides much of the foundation on which Peritz rests his ultimate conclusions about competition policy in America, not only in the decades before the New Deal, but in our own time as well.

I. The legislative history of the Sherman Antitrust Act

\section{A. A new rhetorical history}

Peritz commences his history of competition policy by examining the congressional debates beginning in 1888 that ultimately culminated in passage of the Sherman Act in 1890. In his Intro- 
duction, Peritz argues that this episode is a logical starting point for extended analysis because the congressional debates, along with related opinions voiced at the time in the popular press, constituted the "first extended public debate in America about competition policy." 20 Peritz argues that the floor debates and committee reports preceding Sherman Act passage gave birth to modern competition discourse: "The rhetorical practices [in these debates and reports] set the terms of debate over political economy in twentieth century America-debate reflecting two sharply contrasting views of free competition."21

Peritz describes the congressional debates as an extended confrontation between two strongly divided "rhetorical camps": a "Sherman faction" and its opposition. Peritz stresses that these differing factions developed their contrasting views in a context in which older, classical conceptions of a beneficent social order premised on liberty of contract, vigorous and open competition, and limited government increasingly were being called into question by the widespread new prevalence of cartelization and tighter forms of giant combination. Simultaneously, he notes, the worsening economic situation of small businesses and the ongoing expansion of the ranks of industrial workers seemed to be eroding the "rough equality and economic independence" that had been deemed an essential basis for virtuous government in "republicanist" visions of political liberty. ${ }^{22}$

Senator Sherman initiated the congressional struggle by introducing a bill to condemn all arrangements made or tending "to prevent full and free competition ... or which tend to advance the cost to the consumer." 23 Peritz relates, however, that 15 months later, battle between the two contending congressional factions produced a 31-28 roll call vote referring Sherman's bill to the Senate Judiciary Committee. ${ }^{24}$ That committee then rapidly

$20 I d$.

$21 \quad I d$. at 5 .

22 Id. at $11,21-24$.

23 See id. at 13 (quoting Sherman's antitrust bill).

24 Id. at $13,14$. 
produced a completely different bill that replaced the language just quoted with common law terminology banning "every contract, combination in the form of trust or otherwise, or conspiracy in restraint of trade or commerce." 25 Within a week after the Committee reported out this new bill, the Senate approved it with only a single dissenting vote. ${ }^{26}$ Several weeks later, the House unanimously approved the Senate bill without change and the bill became law when signed by President Benjamin Harrison on July $2,1890.27$

Peritz distinguishes the two warring camps he finds to have been active in the congressional debates on the basis of their respective reactions to the contemporary rise of expanded cartelization and new, disturbing forms of tighter, large-scale combination. While the Sherman faction saw these new developments as dangerous and unnatural, the opposing camp, says Peritz, perceived the same developments as part of a naturally evolving new economic order. ${ }^{28}$ These differing understandings, he notes, led to differing assessments of what, if any, new government action was needed. Sherman and his allies pushed for government eradication of arrangements that threatened either to prevent full and free competition or to advance consumer prices. ${ }^{29}$ Their congressional opponents wanted more limited government

25 S. 1,51 st Cong., 1st Sess. $\$ 1$ (as reported by the Senate Committee on the Judiciary, April 2, 1890).

26 The lone dissenter was Senator Blodgett (D. N.J.). See 21 Cong. REC. 3153 (1890). Blodgett never participated in the Senate discussions of proposed antitrust legislation and his reason for dissenting remains obscure. See Hans B. Thorelli, The Federal Antrtrust Policy: OriginaTION OF AN AMERICAN TRADITION 201 (1955). In his study, Thorelli speculated that Blodgett's lone contrary vote might somehow have resulted from Blodgett's embrace of the markedly sympathetic general attitude toward corporations displayed at the time by his home state. See id. at 201 n.87.

27 Sherman Antitrust Act, ch. 647, $\S \S 1-8,26$ Stat. 210 (1890) (codified as amended at 15 U.S.C. $\S \S 1-7$ (1994)).

28 PERITZ, supra note 1, at 15.

29 Id. at $13,15,17$. 
protection of competition and greater security for the contracting freedom that seemingly made development of the evolving new order possible. ${ }^{30}$

Peritz relates that only the Sherman faction explicitly invoked the term "industrial liberty" to make its case in the congressional debates. ${ }^{31}$ Nevertheless, he suggests that the basic disagreements between the two camps usefully can be understood as emanations of fundamentally differing interpretations of this phrase. The contrasting interpretations of industrial liberty embraced respectively by the two sides can be conceived, he says, as reflecting either differing understandings of liberty or, alternatively, differing underlying impulses-by one camp toward liberty and by the other camp toward equality. ${ }^{32}$

Peritz reports that the aspect or meaning of liberty that the Sherman faction emphasized was freedom from undue market power. In contrast, the liberty the opposing faction stressed was freedom from governmental power and regulation. These differences, Peritz notes, led to differing regulatory preferences. The Sherman camp actively sought regulation by legislation. Those outside that camp wanted to rely more heavily on regulation through the protection and unimpeded operation of private property rights. ${ }^{33}$

More specifically, Peritz argues, Sherman and his supporters wanted to ban private anticompetitive agreements that restrained the normal leveling force of competition. This, they hoped, would serve to reestablish and protect the system of competitive rivalry among roughly equal participants envisioned in "republicanist" conceptions of industrial liberty. Those who did not share Sherman's factional outlook sought instead to leave room for judicial enforcement of private "remedial" or defensive restraints on economic rivalry, perceiving such restraints to be a legitimate and
$30 \quad I d$. at $16,17$.
$31 \quad I d$. at 18.
$32 \quad I d$. at 17.
33 Id. 
appropriate exercise of freedom of contract. The remedial restraints Sherman's opponents had in mind, Peritz says, were private combinations such as defensive cartels established to combat the excesses either of competition itself, for example, in the form of "ruinous" competition, or of combination, most particularly in the form of harmful trust activity. ${ }^{34}$

If the contending factional interpretations of industrial liberty alternatively are understood not in terms of differing understandings of liberty, but instead in terms of impulses, respectively, toward either equality or liberty, Peritz argues, Sherman and his allies should be seen as the faction impelled toward equality, while their rhetorical rivals should be seen as the faction more centrally concerned with liberty. The members of the Sherman camp, he relates, believed that government protection of unimpeded competition would promote widespread economic prosperity, which, in turn, would contribute to realization of the republicanist vision of rough competitive equality. This equalityoriented vision of "industrial liberty," notes Peritz, left no legitimate place for cartel price fixing. ${ }^{35}$

The opposing faction's conception of "industrial liberty," however, informed by an impulse toward liberty instead of toward equality, did allow room for some price-fixing combinations. The embrace of such a "liberty-oriented" conception led congressmen in this camp to seek more limited government regulation of contracts in restraint of trade, in order to allow room for the type of defensive restraints on rivalry just noted. These congressmen feared that more sweeping regulation detrimentally might infringe the freedom of contract critically needed to promote economic growth and prosperity. ${ }^{36}$

Peritz notes that notwithstanding such fundamental ideological differences, the two camps shared some important commonalities. Both factions centrally hoped for the prevalence of fair prices and

$34 \quad I d$. at $15-18$.

35 Id. at 17.

36 Id. 
profits in the economic system, for the benefit of producers and consumers alike. Both camps also deemed government intervention in the economy to be appropriate to help achieve this result. Sherman and his allies wanted to rely, when necessary, upon active government interdiction of private threats to full and free marketplace competition as a means to produce such fair levels of prices and profits. Their rhetorical rivals, however, endorsed a different pattern of government activity. They supported both prohibition of a more limited range of "excessive" combination activity and judicial enforcement of those collective restrictions of rivalry that merely restored the fair prices that had been eliminated either by excesses of competition or by bad forms of combination engaged in by others. ${ }^{37}$

Peritz places great stress on the new language the Senate Judiciary Committee adopted to replace Sherman's original bill. Peritz argues that this language drew on a long-established common law tradition rooted in "liberty of contract and private property rights including the right to a fair profit." $38 \mathrm{He}$ believes this language effected a retreat from Sherman's desire to enforce "full and free competition." ${ }^{39}$ The Committee bill's embrace of alreadyestablished, limited common law prohibitions on private restraints of trade, he urges, reflected a non-Sherman-like desire to intervene only to eliminate "excesses" of both combination and competition, while otherwise leaving the competitive economic system alone to evolve naturally in a manner that might include the establishment of "reasonable" private restraints on competitive rivalry ${ }^{40}$

Peritz emphasizes, however, that the new bill not only invoked common law prohibitions, but simultaneously established a variety of unprecedented and potentially severe remedies for their violation. Noting that both Houses of Congress adopted the Committee bill practically unanimously after only a few hours of floor

37 Id.

38 Id. at 20.

39 Id. at 20, 25.

40 See id. at 20-25. 
debate, Peritz concludes that the bill offered a kind of synthesis or accommodating balance between old common law liability standards and new remedies."1 The Sherman Act, he says, "seemed to be reaching for a middle ground between the rhetorics of industrial liberty and fair price, between their logics of competition policy and private property rights, and between their statist and libertarian approaches." 42

\section{B. Assessing the original factional foundations of American antitrust law}

1. WHAT AND WHERE IS A FACTION? The central theme and most novel contribution of Competition Policy in America 1888-1992 is its depiction of American competition policy over the last hundred years as the product of ongoing interaction between two great rhetorical factions: one primarily committed to rough equality, uninhibited competition, and freedom from the dangers posed by excessive private economic power, and the other primarily concerned to protect freedom from excessive government regulation and determined to uphold private property rights and contracting liberty. This central interpretative approach raises basic questions of methodology and evidence. Two particularly important, interrelated questions are: What exactly constitutes a "faction" and how do we know when one is present and powerfully influencing legal development in an ongoing struggle with an opposing ideological camp?

"Faction," of course, could connote a variety of different things. In some contexts, the word might be used to mean simply a group of persons who happened to coalesce at a particular moment to support or to oppose a specific measure identified with some larger social group, concern, or value. Thus, anyone who happened to vote for, or to uphold, a particular federal health and safety measure might be declared part of a "prohealth and safety" faction or a "nationalist" as opposed to a "states'-rights" faction or perhaps even a "proregulation" as opposed to a "liberty of

\footnotetext{
41 Id. at 20, 25-26.

$42 \quad I d$. at 26.
} 
contract" faction with regard to that particular measure. The legislators or judges joining together in support of that particular measure might be so designated despite the fact that they might divide among themselves on various other federal health and safety questions and that only some of them, therefore, might be considered part of the "health and safety" or "nationalist" or "proregulation" faction supporting other particular federal health and safety measures.

Alternatively, "faction" might be used instead to highlight ongoing general differences among an institution's members in their sympathy toward any one of numerous outside groups or basic values that one might choose to emphasize. In this sense, congressmen or Supreme Court Justices might be grouped, for example, into pro- and antilabor factions, or pro- or antibusiness factions, or pro- or antimajoritarian factions.

"Faction" also might be used in still a third sense to mean a group having substantial continuity in its membership over time and distinguished by its members' embrace of a particular shared, guiding philosophy of a broader sort that is thought to have differed markedly from the particular shared, guiding philosophy embraced by those comprising an opposing ideological faction.

Of these three possibilities, ${ }^{43}$ the third seems closest to what Peritz means by "faction." How well does such a "factional" framework fit the congressional deliberations giving rise to the Sherman Act?

2. THE LEGISLATIVE HISTORY OF THE SHERMAN ACT Peritz's depiction of the congressional deliberations preceding enactment of the Sherman Act differs strongly from the varied accounts of these debates offered by other scholars over the last several decades. In his landmark work of the mid-1950s, ${ }^{44}$ Hans Thorelli, for example, concluded that the debates reflected a high degree of philosophical consensus in Congress with regard to the virtues of

43 While these possibilities do not exhaust the range of conceivable meanings of "faction," they provide a useful starting point for assessing the picture Peritz presents.

44 THORELLI, supra note 26. 
unrestricted competition. He also found that congressmen in general embraced an "economic egalitarianism" incorporating various major currents of 19th-century thinking. Thorelli concluded that Congress as a whole sought to promote competition and that its members were concerned simultaneously with economic opportunity, wealth distribution, efficiency, and political freedom. He further believed that while consumers were the ultimate beneficiaries of the Sherman Act, Congress as a whole likely had small businesses in mind as the intended immediate beneficiaries. ${ }^{45}$

William Letwin, in his well-known 1965 book Law and Economic Policy in America: The Evolution of the Sherman Antitrust $A c t,{ }^{46}$ emphasized that congressmen in general, including both Senator Sherman and the Senate Judiciary Committee members who replaced Sherman's bill with a provision of their own, strongly believed in competition but at the same time did not wish to prohibit all business combinations. ${ }^{47}$ Letwin concluded that the Committee's bill did not reflect any basic philosophical disagreement with Sherman but instead "differed mainly in providing a greater number of more severe penalties." 48

In both his 1978 book The Antitrust Paradox ${ }^{49}$ and his earlier study of the Sherman Act's legislative history, ${ }^{50}$ Robert Bork, too, emphasized widespread philosophical consensus among the congressmen who debated antitrust legislation from 1888 to the middle of 1890 . Bork, however, detected in the debates an overwhelmingly dominant congressional concern for economic efficiency or "consumer welfare maximization." 51 In the early 1980s,

45 See id. at 564-72 (1955).

46 William Letwin, Law and Economic Policy in America: The EvoLUTION OF THE SHERMAN ANTTrRUST ACT (1965).

47 Id. at 89, 94, 96-97.

48 Id. at 94.

49 Robert H. Bork, The Anttrrust Paradox (1978).

50 Robert $\mathrm{H}$. Bork, Legislative Intent and the Policy of the Sherman Act, 9 J. L. \& EcoN. 7 (1966).

s1 See, e.g., BoRK, supra note 49, at 56-66. 
Robert Lande challenged Bork's interpretation and contended that Congress as a whole had multiple economic, social, and political goals in mind when it passed the Sherman Act. Lande found, however, that Congress was concerned much more strongly with some of these goals than with others. In particular, Lande concluded, Congress primarily sought to attack unfair wealth transfers from consumers to sellers resulting from supracompetitive pricing. In cases of conflict, Lande found, Congress intended to subordinate all other goals to this primary aim. ${ }^{52}$

In a major 1988 study, ${ }^{53}$ David Millon surveyed at length 19thcentury republican and liberal concerns for the threats to individual liberty posed by concentrated economic and political power. $\mathrm{He}$ argued that such concerns provided the motivation and intellectual context for congressional passage of the Sherman Act in 1890. Millon did not, however, suggest that one group of congressmen adopted a "republican" perspective while others were inspired instead by liberal ideas. Rather, Millon concluded that Congress as a whole was influenced by a traditional mixture of republican and liberal ideas and sought to prevent the harms to democratic processes, to consumers, and to competitors that republican and liberal thinking highlighted as the product of artificially acquired, excessive economic power.

Numerous other works, of course, also have addressed the legislative history of the Sherman Act. Some of these also have explored at length the larger contemporary context of political and economic thinking out of which the Sherman Act arose. ${ }^{54} \mathrm{~A}$ number of articles have found a congressional desire to further simultaneously a variety of economic, social, and political goals, but have pictured the origins of that desire in a somewhat different

52 See Robert H. Lande, Wealth Transfers as the Original and Primary Concern of Antitrust: The Efficiency Interpretation Challenged, 34 HASTINGS L.J. 67 (1982).

53 David Millon, The Sherman Act and the Balance of Power, 61 S. CAL. L. Rev. 1219 (1988).

54 See James May, Antitrust in the Formative Era: Political and Economic Theory in Constitutional and Antitrust Analysis, 1880-1918, at 50 Oнiо ST. L.J. 257, 258-300 (1989). 
way than have the various authors already noted. 55 Other writers have offered still other distinctive interpretations of congressional intent. 56 None of the various prior accounts of the congressional deliberations, however, have described them as Peritz does, as an extended battle between two sharply divided ideological and rhetorical factions, much less a two-sided ideological conflict in which Sherman's basic antitrust policy goals were rejected through congressional passage of the statute bearing his name. Why does Peritz reach such a dramatically different conclusion regarding this much reviewed legislative record? Ultimately, how compelling is his argument?

Peritz's view appears to rest on at least three important but analytically separate claims. The first claim is that despite the nearly unanimous congressional vote in favor of the final bill, not all contemporary congressmen shared the sweeping position Peritz attributes to Sherman that all price-fixing combinations should be banned, even if established defensively to combat ruinous competition or distortions caused by "trust" activity. The second claim is that those congressmen wanting to leave room for "reasonable" restraints of this type were not merely an isolated handful of members with atypical views. Instead, it is claimed, these members constituted a powerful faction that ultimately was able to prevail over Sherman's faction on the critical roll call vote that referred Sherman's bill to the Judiciary Committee. The third claim is that the congressmen in each of these two powerful

55 See, e.g., 1 EARL Kintner, Federal AnTITrust Law $\$ 4.18$ (1980); John Flynn, The Reagan Administration's Antitrust Policy, "Original Intent" and the Legislative History of the Sherman Act, 33 ANTITRUST Bull. 259 (1988); Eleanor Fox, The Politics of Law and Economics in Judicial Decision Making: Antitrust as a Window, 61 N.Y.U. L. REv. 554, 563-67, 584-85 (1986); Eleanor Fox \& Lawrence A. Sullivan, AntitrustRetrospective and Prospective: Where Are We Coming From? Where Are We Going?, 62 N.Y.U. L. REv. 936 (1987); May, supra note 54.

56 See, e.g., Thomas C. Arthur, Farewell to the Sea of Doubt: Jettisoning the Constitutional Sherman Act, 74 CAL. L. REv. 263 (1986); Clark, Antitrust Comes Full Circle: The Return to the Cartelization Standard, 39 VAND. L. REV. 1125 (1985). 
camps were not simply an eclectic collection of members pragmatically coalescing in order to support or oppose Sherman's original bill on a diversity of grounds. Instead, Peritz asserts, these two factions were ideologically cohesive groups whose members joined forces on the basis of their common embrace of one of two distinctly different configurations of basic philosophical commitments.

The congressional record supports the first of these claims much more strongly than it supports either the second or third assertion. Peritz clearly is right in pointing out that both within and outside of Congress in 1890, not everyone concerned about contemporary cartelization and trusts supported an across-theboard ban on price fixing that would bar the establishment of defensive, countervailing cartels designed merely to insure a "fair" return. Peritz's next two claims, however, are considerably less compelling.

Peritz relies on three aspects of the congressional record to support his depiction of the congressional deliberations as an extended struggle between two ideological factions that Sherman's camp failed to win. First, he highlights the comments of particular speakers in the debates to illustrate the two factions' respective rhetorics and commitments. Second, as previously mentioned, Peritz cites the 31-28 roll call vote referring Sherman's bill to the Senate Judiciary Committee as an important product of the factional struggle he believes dominated the debates. Third, he stresses the differences between the language of Sherman's bill and the language of the bill the Committee actually reported out and that Congress passed.

Peritz cites comments by Senators Sherman (R. Ohio), ${ }^{57}$ Teller (R. Colo.), ${ }^{58}$ George (D. Miss.),, 5 and Jones (D. Nev.), ${ }^{60}$ and by

57 PerITZ, supra note 1, at 14 (citing 21 CoNg. Rec. 2457 (1890)).

58 Id. at 15 (citing 21 CONG. REC. 2561 (1890) and 20 CoNG. ReC. 1457 (1889)).

59 Id. at $309 \mathrm{n} .18$ (citing 21 CoNG. Rec. 1768 (1890)).

60 Id. at 15 . 
Representative William Mason (R. Ill.) ${ }^{61}$ to illustrate the thought of the "Sherman faction." He cites remarks by Senators Platt (D. Conn.), ${ }^{62}$ Edmunds (R. Vt.), ${ }^{63}$ and Hoar (R. Mass.), ${ }^{64}$ and Representatives Stewart (D. Ga.) ${ }^{65}$ and Morse (D. Mass.) ${ }^{66}$ to exemplify the ideological stance of the opposing faction. As other writers previously have noted, ${ }^{67}$ the comments of Senator Platt and of Representatives Stewart and Morse do demonstrate that at least some members of Congress wanted to allow "reasonable" defensive cartels in American economic life generally. Indeed, other authors have identified at least one additional member of Congress not noted by Peritz who expressed such a view, Senator Stewart (R. Nev.).68 Prior studies of the legislative history, however, have stressed the rarity of such expressions in the congressional deliberations. ${ }^{69}$ Peritz, in contrast, elevates such views to an importance within the debates at least comparable to the opposite policy position held by Sherman and others like him. Peritz does not cite comments by any additional members of Congress that directly echoed the broad support for defensive cartels voiced by Senator Platt and Representatives Stewart and Morse. ${ }^{70}$ Instead, as

61 Id. at 15 (citing 21 CoNG. Rec. 2561 (1890)).

62 Id. at 16 (citing 21 Cong. Rec. 2729 (1890)); see also id. at 18 (citing 21 Cong. REC. 2720-21 (1890)).

63 Id. at 20 (citing 21 CoNG. REc. 3148, 3152 (1890)); see also id. at 23 (citing 21 CONG. REC. 3151-52 (1890)).

$64 I d$. at 20 (citing 21 Cong. Rec. 3145, 3146, 3152 (1890)).

65 Id. at 16 (citing 21 CoNG. Rec. 5956 (1890)).

66 Id. at 309 n.21 (citing CoNG. REC. 5954 (1890)).

67 See, e.g., Bork, supra note 50, at 22-23, 42; THORELl, supra note 26 , at $190,226$.

68 See, e.g., Thorelli, supra note 26 , at 190 . As already noted, Peritz does mention his namesake in the other House, Representative Stewart.

69 See, e.g., THORELlI, supra note 26 , at 191, 226-27; Bork, supra note 50 , at 23,42 .

70 Peritz associates Senators Edmunds and Hoar with the faction opposing Sherman on the basis of their comments in support of the Judiciary Committee bill that Peritz sees as a rejection of Sherman's philo- 
already noted, Peritz relies on the referral of Sherman's bill to committee and the subsequent congressional adoption of a new bill with completely different wording.

Reliance on the roll call vote that referred Sherman's bill to the Judiciary Committee, as evidence of a strong factional division within the debates, raises significant problems. A prominent problem is the misalignment in the recorded votes for and against referral. If the roll call vote was a climactic moment in a sharply pitched struggle between an ideologically united Sherman faction and an opposing faction embracing a fundamentally different set of philosophical commitments, one would not expect to find the voting pattern that actually prevailed on the roll call vote. Of the three Senators Peritz identifies as members of the rhetorical camp opposing Sherman, only one, Senator Platt, actually voted to refer Sherman's bill to the Judiciary Committee. Both Senator Edmunds, the chair of the Judiciary Committee, and Senator Hoar, another member of the Committee, voted against referring Sherman's bill to their Committee. Of the four Senators Peritz locates within the "Sherman faction," only one, Sherman himself, actually voted to oppose referral of his bill. Two other Senators Peritz identifies with the Sherman camp, Teller and George, voted in favor of referral, while the fourth identified member, Senator Jones, is recorded as having been absent. ${ }^{1}$

sophical outlook and approach. The comments he quotes did not address the question of defensive cartels. Instead, Peritz notes Hoar's comment that the Committee bill was already well understood because it affirmed traditional common law. He quotes Edmunds' similar comment about the bill's adoption of well-known common law language and his comment that the bill would not condemn an individual who got the whole business in a certain trade merely by superior skill and intelligence. See PERITZ, supra note 1 , at 20.

71 See 21 Cong. Rec. 2731 (1890). Peritz does not note the votes of any individual Senators on this roll call vote or offer any possible explanation for the apparent misalignment in the voting pattern. Other accounts of the legislative history have attributed the referral of Sherman's by-then heavily amended bill to growing concerns about both its complexity and its constitutional foundations. See, e.g., LETWIN, supra note 46, at 93; THORELLI, supra note 26, at 199. 
The third aspect of the congressional record that Peritz relies on to support his new rhetorical history of the birth of federal antitrust law is the Judiciary Committee's wholesale replacement of the language contained in Sherman's original bill and congressional enactment of the Committee's version. Leading commentators since the mid-1950s have contended that adoption of the Committee's bill in place of Sherman's did not implement any substantial change in policy, except with regard to remedies. ${ }^{72}$ Peritz strongly seeks to challenge this orthodox view. In doing so, Peritz relies in part on his prior arguments that the debates were an extended struggle between philosophical factions, inferring that if this was so it is reasonable to interpret the complete displacement of Sherman's preferred language as a rebuff to the philosophical premises underlying that language. He also stresses Senator Sherman's expressed unhappiness with the referral and displacement of his own bill. ${ }^{73}$ In addition, Peritz offers an explanation to harmonize his conclusion of sharp factional warfare and last-minute substantive policy change with the fact that Congress passed the Committee's version with only a single dissenting vote and after only a few hours of not very pointed additional debate. As already noted, Peritz suggests that such near unanimity became possible despite fundamental factionalization within Congress because the final bill's combination of common law liability standards and "un-common law" remedies constituted a synthesis or attempt to occupy a middle ground and thus may have offered something to both factions.

Members of the 51 st Congress might or might not have thought that the Committee's displacement of Sherman's wording effected a major change in liability standards. Congressmen sympathetic to a reasonable cartel argument might have thought that such an argument would stand a better chance under the general language of section 1 of the Sherman Act as passed than it would

72 See, e.g., LETWIN, supra note 46, at 94; THORELLI, supra note 26 , at 228; Bork, supra note 50, at 46-47.

73 PeRITZ, supra note 1, at 14 (citing Mr. Sherman Gives Up Hope, N.Y. Times, Apr. 8, 1890, at 4 (quoting comments appearing in the ST. LOUIS GLOBE-DEMOCRAT)). 
have under Sherman's bill. On the other hand, there would not seem to be anything in the mere language of section 1 as adopted to preclude a belief that no significant change in liability standards actually had been accomplished. Prior studies of the legislative history have argued that the members of the 51st Congress probably embraced this latter belief, citing the rapidity with which the substitute bill was adopted and the fact that throughout the debates Sherman strongly had insisted that his bill did no more than to adopt the common law standards that the Committee's bill embraced explicitly through its language of "contracts, combinations . . . , and conspiracies in restraint of trade." "74

If the general wording of the Sherman Act by itself does not clearly indicate the extent of substantive policy change it implemented, what of the larger legislative record beyond just the persons and developments Peritz cites? How strongly does this record support the assertion that Sherman's philosophical outlook lost out in a rhetorical conflict between two relatively cohesive ideological factions, the first committed to full and free competition, rough competitive equality, and across-the-board hostility to cartels, and the second dedicated to competition limited by vigorous protection of private property rights and liberty of contract and generally supporting reasonable, defensive cartels designed merely to insure a "fair" return?

Appeal to the larger record does not appear to remedy the evidentiary problems already noted. Instead, it seems to undercut this picture of sharp, stable philosophical bifurcation within Congress. Consider, for example, the positions taken by the Senate Judiciary Committee members. ${ }^{75}$ Within 6 days after the referral of Sherman's bill, these members unanimously agreed ${ }^{76}$ to

74 See, e.g., LETwIN, supra note 46, at 95-96; THORELLI, supra note 26 , at 183,228 ; Bork, supra note 50 , at $45-47$.

75 At the time that Sherman's bill was referred to the Senate Judiciary Committee, the Committee consisted of Republican Senators Edmunds (R. Vt.), Hoar (R. Mass.), Ingalls (R. Kan.), Evarts (R. N.Y.), and Wilson (R. Iowa) and Democratic Senators Coke (D. Tex.), Vest (D. Mo.), George (D. Miss.), and Pugh (D. Ala.). Thorelli, supra note 26, at 199. 
replace Sherman's bill with new liability standards that apparently were written by the Committee chair, Senator Edmunds. ${ }^{77}$ At least four of these members, however, previously had expressed support for the general liability standards and policy aims of Sherman's original bill. ${ }^{78}$ Should we infer that they voted to scrap Sherman's original bill because they suddenly changed their general factional allegiance? Or, alternatively, should we conclude that they embraced Edmunds' new draft because they saw no substantial difference in the liability standards it proposed while finding Edmunds' draft superior in other respects?79

The larger legislative record does offer additional evidence of sympathy for "reasonable" restraints. Indeed, many members of Congress beyond those mentioned by Peritz expressed some support for defensive price-fixing combinations designed to insure a "fair" return. The views of these additional members, however, do not fit neatly within the picture of ideologically opposed factions set out in Competition Policy in America 1888-1992. Instead, they tend to undermine the view that Congress was split into two sharply opposed camps divided on the general philosophical lines Peritz suggests.

Many more congressmen expressed support for certain specific types of defensive cartels than proclaimed sympathy for defensive cartels in general. In the congressional debates, selective support for defensive price fixing typically was justified not through explicit invocations of general property rights principles or liberty of contract ideology, but instead through expressions of sympathy for the plight of farmers and laborers in particular. Senators 212.

77 See, e.g., LETWIN, supra note 46, at 94; THORELLI, supra note 26, at

78 These four were the Democratic members, Senators George, Coke, Vest, and Pugh. For a summary of the views expressed during the debates by these members of the Senate Judiciary Committee, see Bork, supra note 50 , at $17-18$.

79 It might have been thought, for example, that Edmunds' draft addressed more satisfactorily the constitutional basis for the legislation or desirably eliminated the complexity that characterized the amended version of Sherman's bill that had been referred to the Committee. 
hoping to shelter defensive price-fixing combinations among farmers or laborers overwhelmingly sought to achieve such protection by expressing support for a specific exemption for these groups rather than by mobilizing as a separate ideological faction to promote a general liability standard contrasting with the one in Sherman's bill. ${ }^{80}$ Thus, when Senator George, the chief proponent of such a farmer-labor exemption, offered his own bill as an alternative to Sherman's proposal, he simply added this exemption while retaining the same general liability tests set out in Sherman's bill. ${ }^{81}$

Senator George was not the only Senator who supported the "full and free competition" language that Sherman proposed while simultaneously desiring special protection for at least farmers and laborers, if not for defensive cartels in general. Sherman himself declared that even without an express exception, his bill would not in fact cover combinations by farmers or by laborers to increase their prices or wages. ${ }^{82} \mathrm{He}$ proclaimed that he was happy, however, to amend his own bill to provide an explicit exception for such combinations and offered an amendment adopting Senator George's exemption language..$^{83}$ The Senate as a whole voted

80 On the congressional debates, amendments, and votes on a farmerlabor exemption, see, e.g., Bork, supra note 50, at 10, 12, 31; THORELLI, supra note 26 , at $193,197,231-32$.

81 On March 26, 1890, Senator Gray adopted Senator George's suggested provision as his own and offered it as an amendment. Like Sherman's bill, George's provision banned contracts, arrangements, and combinations "made with a view of preventing or which tend to prevent ... full and free competition ... or which shall have the effect of advancing the cost of any such article to the consumer." See 21 Cong. REC. 2657.

82 See 21 CoNG. REC. 2562, 2611.

83 See 21 CoNG. REC. 2611-12. The amendment proposed to add the following language to $\S 1$ of Sherman's bill:

Provided, That this act shall not be construed to apply to any arrangements, agreements, or combinations between laborers, made with the view of lessening the number of hours of their labor or of increasing their wages; nor to any arrangements, agreements, associations, or combinations among persons 
to add this amendment to Sherman's bill prior to the time it was referred to the Judiciary Committee. ${ }^{84}$

The leading congressional opponent of such protection for farmer or labor price-fixing combinations was Senator Edmunds, the chair of the Judiciary Committee. ${ }^{85}$ Indeed, Edmunds may have been responsible for the absence of any farmer or labor exemption in the Committee's bill. ${ }^{86}$ It is generally thought, however, that Edmunds drafted section 1 of the Sherman Act. ${ }^{87} \mathrm{He}$ thus was a key architect of the document that Peritz pictures as a retreat from the full and free competition position advocated by the Sherman faction. Accordingly, it seems difficult to contain Edmunds' thinking comfortably within either a "full and free competition" faction supporting Sherman's original bill without allowance for defensive cartels or a rival faction opposing Sherman's bill in order to leave room for private, defensive restrictions on competition.

In short, Peritz aptly points out that consideration of antitrust legislation implicated basic issues not only of competition, but also of liberty, equality, private property rights, and the legitimate scope of government activity. In addition, he convincingly stresses the presence of some striking initial differences of approach and emphasis among the members of Congress as they debated this legislative initiative. What he has not clearly demonstrated, however, is that these differences reflected fundamental philosophical disagreements that impelled the members to coalesce into the two particular factional groupings Peritz suggests, like iron filings drawn to two opposite but comparably powerful poles of a single giant magnet.

engaged in horticulture or agriculture, made with a view of enhancing the price of their own agricultural or horticultural products.

21 CoNG. ReC. 2612.

84 See 21 CoNG. REC. 2612.

85 See, e.g., ThORELL, supra note 26, at 197, 231-32.

86 See, e.g., id. at 232; Bork, supra note 50, at 12, 31.

87 See, e.g., ThORELI, supra note 26 , at 212; LETWI, supra note 46 , at 94 . 
II. The Sherman Act in the courts through the rise of the classical rule of reason

\section{A. Factional fighting in the formative era of American antitrust jurisprudence}

After discussing the congressional antitrust deliberations between 1888 and 1890, Peritz next addresses the battles over Sherman Act interpretation that were waged in the Supreme Court during the two decades following the Act's passage. He argues that these battles largely, if not completely, picked up where the factional fighting in Congress left off. After 1890, he notes, "Literalist" and "Rule of Reasonist" camps on the High Court took the rhetorical places of the Sherman faction and its opposition. The "Literalists," says Peritz, strongly held to the small dealer, individualist vision of competitive rivalry embraced by the Sherman camp. The "Rule of Reasonists," however, stressed the inviolability of private property rights, especially liberty of contract, sometimes urging this position more emphatically than had the congressmen who earlier supported reasonable restraints to secure a "fair return." 88

Peritz pictures the Court's antitrust cases between 1890 and 1911 as falling into two overlapping cycles. Each of these cycles, he says, began with deep intercamp conflicts sparked by "factional commitments to competition policy and common-law property rights." 89 Peritz finds, however, that in each of these two cycles the two factions were able to reach "surprisingly swift resolutions" of their differences..$^{90}$ The cases in the first cycle of conflict and resolution involved the treatment of associations, specifically, commercial cartels and labor unions. The cases in the second cycle focused instead on the proper treatment of large corporate size and the legality of trusts, which typically had been established through a combination of mergers and questionable forms of competitive rivalry.

\footnotetext{
88 See PERITZ, supra note 1 , at 27.

$89 \quad I d$. at 28.

90 See id.
} 
1. THE FIRST CYCLE Peritz notes that in his 1897 opinion for the Court in United States v. Trans-Missouri Freight Association,91 Justice Peckham rejected the holding and reasoning of lower court judges who, like most lower federal court judges in cases up to that time, had interpreted the Sherman Act to incorporate common law restraint of trade doctrines. The lower court judges, says Peritz, believed that such common law doctrines required a determination of the "reasonableness" of challenged restraints of trade. They accepted the defendant railroads' arguments that their cartel was lawful because it only established reasonable prices in an effort to avert ruinous competition. In so holding, Peritz contends, the lower court judges in Trans-Missouri strongly echoed the support for defensive restraints earlier voiced by Sherman's factional opponents in the 51 st Congress. ${ }^{92}$

On appeal, Peritz notes, Justice Peckham rejected such views and instead embraced the outlook of Sherman's congressional camp. Writing for a five-Justice Literalist majority, Peckham declared that the Sherman Act went beyond the common law to condemn all contracts, combinations, and conspiracies in restraint of trade and not merely those that might have been found unreasonable at common law. He announced that "competition, free and unrestricted is the general rule" ${ }^{13}$ and that only prices fixed by competition could be deemed reasonable. ${ }^{94}$ Justice White, writing for the four Justices in the Rule of Reasonist minority, allied himself, conversely, with the views of the defendants, the lower court judges, and Sherman's rhetorical foes in the congressional debates. ${ }^{95}$ In short, Peritz asserts that the Trans-Missouri opinions announced the Court's division into two opposing factions com-

\footnotetext{
$91 \quad 166$ U.S. 290 (1897).

92 See PerItZ, supra note 1, at 29-30.

93 United States v. Trans-Missouri Freight Ass'n, 166 U.S. 290, 333 (1897).

94 See PerrTz, supra note 1, at 30.

95 See id.
} 
mitted, respectively, "to either 'free competition' or 'freedom of contract'."96

Peckham's Literalist opinion, Peritz relates, primarily expressed fear that, if not checked, private restraints of competition would drive out of business "small dealers and worthy men," whose demise would be a great social loss even if a particular restrictive combination effected a reduction in the price of the commodities its members sold. ${ }^{97}$ The Literalists believed that cartels were harmful not only because they raised prices above competitive levels, but also because they threatened the "republicanist" ideal of rough equality in economic life. 98 The Literalists feared, for example, that the collapse of a competitive market system built on rivalry among such independent, roughly equal firms and entrepreneurs seriously would undermine virtuous republican government. Peritz explains that this view partly was based on a belief that "an independent entrepreneur could be an independent citizen, while a 'servant or agent of a corporation' could not." 99 The Literalists, he says, also feared that the rise of giant new private centers of wealth increased the danger that republican government might be imperiled through direct political corruption. ${ }^{100}$

Peritz concludes that the dissenting Rule of Reasonist faction was haunted chiefly by a distinctly different general fear, the Hobbesian specter of a potential descent into anarchic industrial warfare. He relates that Justice White, for this faction, rhetorically called for the "utmost liberty of contracting" as the essential antidote for such a social and political danger. ${ }^{101}$ In particular, White

\footnotetext{
96 See id. at 31.

97 Peritz finds this "republicanist concern for a disappearing class of independent entrepreneurs" to be the dominant theme in Peckham's opinion for the Literalist majority in Trans-Missouri. Id. at 35.

$98 \quad$ See id. at 32.

99 Id. at 31 .

100 See id.

101 Id. at 32.
} 
urged that both businessmen and laborers should be left free to form private combinations designed to insure a fair return in the face of otherwise excessively intense economic competition. ${ }^{102}$

Peritz finds that the following year, in the Court's second railroad cartel case, the "incompatible visions of commercial society" 103 held respectively by the Court's two rhetorical factions produced the same split among the Justices. ${ }^{104}$ In United States $v$. Joint Traffic Association, ${ }^{105}$ the Literalists continued to maintain that congressional competition policy overrode the common law. The Rule of Reasonists, who dissented but did not produce any new written opinion of their own, continued to look sympathetically, says Peritz, on defensive combinations established to guarantee fair remuneration. ${ }^{106}$

Peritz notes, however, that in the midst of this continuing factional division, important rhetorical changes appeared. Peckham, for the Literalist majority, no longer stressed the importance of the economic welfare of "small dealers and worthy men." Instead, he emphasized lower rates as the main benefit of untrammeled competition. Simultaneously, Peckham adopted a new stance toward the common law. In Joint Traffic, Peritz relates, Peckham departed from his earlier approach in Trans-Missouri and now invoked a traditional aspect of common law restraint of trade doctrine itself to condemn the railroad cartel at issue in the case. ${ }^{107}$ Noting the long-established common law distinction between direct and ancillary restraints, Peckham declared that the defendants' combination was unsupportable because its direct and immediate effect was "to prevent any competition what-

\footnotetext{
102 Id.

103 See id. at 35.

104 Joint Traffic was a five-to-three decision. Justice McKenna did not participate in decision of the case. See United States v. Joint Traffic Ass'n, 171 U.S. 505, 578 (1898).

105171 U.S. 505 (1898).

106 See PERITZ, supra note 1, at 35-36.

$107 \quad$ See id. at 35.
} 
ever."108 Peckham's opinion in Joint Traffic, says Peritz, later proved to be the initial step toward establishment of the factional accommodation that brought to a close the first of the two cycles of early Supreme Court Sherman Act jurisprudence. ${ }^{109}$

Peritz points out that the Court reached unanimous decisions in almost all the cartel cases it addressed during the two decades following its decision in Joint Traffic. ${ }^{110}$ He traces this new unanimity to Justice Peckham's 1899 opinion for a unanimous Court in United States v. Addyston Pipe \& Steel Co.,111 which condemned a bid rigging agreement among major producers of iron pipe. Peritz suggests three reasons why both of the Court's philosophical factions joined in Peckham's opinion and why no other Justice felt a need to offer a written opinion of his own. ${ }^{112}$ First, Peritz argues, both factions deemed the secret arrangement to be illegitimate because it defrauded the public. Second, while Justice Peckham continued to declare that the level of prices collectively set by the defendants was doctrinally irrelevant, Peckham went on to note that in any case the prices set by these defendants in fact were unreasonable. ${ }^{113}$ Finally, Peritz relates, Peckham buttressed his condemnation of the cartel by invoking reasoning reminiscent of the logic the Court had used 4 years earlier to uphold a labor injunction in In re Debs. ${ }^{114}$ In this connection, says Peritz, Peckham appealed to the "liberal sensibilities" of the Rule of Reasonist faction by arguing that the federal government legitimately

108 United States v. Joint Traffic Ass'n, 171 U.S. 505, 565 (1898). This stress on direct and immediate effects echoed Peckham's earlier comment in Trans-Missouri declaring the cartel at issue in that case harmful because its "direct, immediate, and necessary effect [was] to put a restraint upon trade or commerce." 166 U.S. at 342.

109 See Peritz, supra note 1, at 35-36.

110 See id. at 37.

$111 \quad 175$ U.S. 211 (1899).

112 See PerITZ, supra note 1 , at 36.

113175 U.S. 211, 235-38 (1899).

114158 U.S. 564 (1895). 
could block not only state interference with interstate commerce, but also similar interference with interstate commerce arising from private associational activity like the cartel challenged in Addyston Pipe. ${ }^{115}$ Both factions could endorse the federal government's use of the Sherman Act as the vehicle to eliminate such interference with interstate commerce, Peritz notes, because the challenged cartel simultaneously ran afoul of each faction's own preferred interpretation of the Act. Because the cartel "was fraudulent and called for unreasonable prices, it met both the Literalist (direct) and Rule of Reasonists (unreasonable) tests, both common law standards, for illegality."116

Peritz concludes, however, that the factional accommodation reached by the turn of the century and reflected in the Supreme Court's unanimity in almost all cartel cases after Joint Traffic came at a substantial ideological cost. Specifically, the earlier republicanist underpinnings of the Literalist position, its earlier concerns for the economic viability of "small dealers and worthy men," were abandoned. Peritz finds that the two Court factions converged by mutually embracing, instead, "a libertarian rhetoric for antitrust, situated comfortably within Lochner's constitutional framework, founded in liberty of contract."117 Peritz relates, however, that this "rhetorical shift seemed to have no practical consequences for cartel cases: Both antitrust visions, both free competition and freedom of contract rhetorics, portrayed cartels as always direct, always unreasonable, and thus always illegal restraints of trade."118

By the close of the first cycle of Sherman Act adjudication, Peritz declares, Literalists and Rule of Reasonists alike not only embraced such blanket condemnation of price fixing, but also applied it to labor combinations seeking higher wages as well as to business cartels seeking higher prices. ${ }^{119}$ The Court's hostility

\footnotetext{
115 See PerITZ, supra note 1, at 36-37.

$116 \quad$ Id. at 37.

117 See id.

118 Id.

119 Id. at 37-38.
} 
to both business cartels and labor union strikes rested, says Peritz, on a fundamental conception of competition "as rivalry between individuals." 120 This apparent evenhandedness in the Court's treatment of business and labor, however, was belied, he stresses, by a deeper discrepancy in the Court's perception of individualism in business and labor contexts more generally. The Court treated business cartels, like striking unions, as collections of individuals. The High Court treated very differently an association of persons who joined together as a corporation. The Court, notes Peritz, deemed such an association to constitute collectively only a single individual in law, and therefore found it not to be a combination at all for antitrust purposes. ${ }^{121}$

2. THE SECOND CYCLE Peritz believes that despite the early establishment of High Court unanimity in cartel cases and continuing changes in Court membership, the Supreme Court continued to be divided into a "free competition" Literalist faction and a "freedom of contract" Rule of Reasonist faction up through 1911, not only in antitrust cases but in its jurisprudence more generally. The specific legal issues over which the two factions fought, however, changed as time went on. The second cycle of Sherman Act cases, says Peritz, posed more sharply than had previous cases the issue of when business aggregations should be treated as collections of persons or, alternatively, as merely a single individual in law. Peritz finds that the first great factional battle over this issue was fought in Northern Securities Co. v. United States. ${ }^{122}$ Peritz devotes considerable attention to this case, partly because he finds that it led unexpectedly to new fragmentation within the Literalist camp itself. ${ }^{123}$

a. Northern Securities: vigilance against anticompetitive combinations versus protection of essential rights of property and association In his plurality opinion for himself and Justices Brown, Day, and McKenna in Northern Securities, Justice Harlan

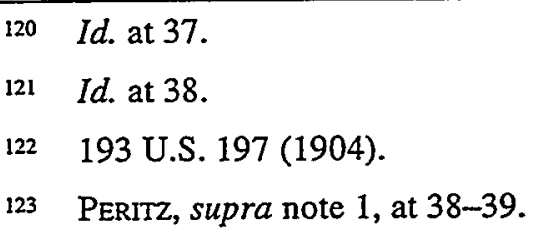


strongly reiterated the primacy of competition as the rule of trade. ${ }^{124} \mathrm{He}$ expressly reaffirmed the Literalists' previously established ban on every contract, combination or conspiracy directly restraining interstate trade. In so doing, Harlan specifically noted that some people believed the recent rise of enormous private wealth made the rule of competition more necessary than it ever had been before. While Peritz suggests that this comment might be taken as the "last residue" of the Literalists" earlier republican commitment to "small dealers and worthy men," 125 he acknowledges that Harlan never referred explicitly to Trans-Missouri's "republicanist" rhetoric. ${ }^{126}$ Instead, Harlan supported his condemnation of the Northern Securities merger on the authority of prior Supreme Court precedent banning "all direct restraints" and on the basis of the Court's duty to apply faithfully the rule of competition that Harlan believed Congress itself had embodied in the Sherman Act. Harlan noted that the Court previously had held unanimously in Addyston Pipe that Congress constitutionally could decree such a rule without violating the constitutional guarantee of liberty of contract. Avoiding the troublesome issue that Northern Securities raised as to whether Congress could restrict the fundamental right to sell one's own property, including corporate stock, Harlan merely labeled the challenged merger another example of an anticompetitive combination and condemned it on the authority of Addyston Pipe. ${ }^{127}$

Justice Brewer, an original member of the Literalist faction, concurred in the result. Peritz emphasizes, however, that Brewer's concurring opinion announced that Brewer now believed that the Sherman Act should be read to ban only unreasonable restraints of

124 The case was decided at a time when Justices Holmes and Day recently had joined the Court, replacing two of the original members of the Rule of Reasonist faction, Justices Gray and Shiras. See THE OXFORD Companion to the Supreme Court of THE United States 985 (Kermit L. Hall et al. eds., 1992) [hereinafter ThE OXFoRD CoMPANION].

125 PERITZ, supra note 1 , at 40.

126 See id. at 41.

127 See id. at $40-41$. 
trade and that the government should not interfere with the basic individual right to buy and sell property. ${ }^{128}$

Justices White and Holmes each wrote a separate dissenting opinion. ${ }^{129}$ Peritz stresses that each of these two opinions underscored the importance of the basic property right of purchase and sale. Stressing that property ownership was the basis of civilized society, Justice White declared that Congress did not have power under the Interstate Commerce Clause to regulate ownership or sale of railroad stock. 130 White believed, says Peritz, that government prohibition of the sale of stock, even to block a massive merger of competing interstate railroad lines, would amount to an unconstitutional taking banned by the Fifth Amendment. ${ }^{131}$ Justice Holmes similarly stressed the fundamentality of property ownership rights. Simultaneously, Holmes expressed agreement with concerns that the congressional "freedom of contract/reasonable combination" faction previously had expressed during the Sherman Act debates with regard to the disintegration of society into atomistic warfare. ${ }^{132}$

Justice Peckham did not write a separate opinion in Northern Securities, but joined in the dissenting opinions of both Justice White and Justice Holmes. Peritz explains Peckham's "desertion to the Rule of Reasonist faction" on the basis of Peckham's continuing, but now differently focused, commitment to liberty. In the price-fixing cases, says Peritz, Peckham had embraced the "competition rhetoric of industrial liberty" in order to stress the importance of protecting the freedom freely to exercise individual judgment in the conduct of a business, particularly the setting

128 See id. at 43.

129 See 193 U.S. 197, 364-400 (White, J., dissenting); 400-11 (Holmes, J., dissenting). Justices White and Holmes concurred in each other's dissenting opinions. Chief Justice Fuller and Justice Peckham each concurred in both of these two dissenting opinions.

130 PerITZ, supra note 1, at 42.

$131 \quad I d$.

132 Id. at $42-43$. 
of product prices, without regard to any constraining agreement with other rivals. In the 1904 Northern Securities case, however, in order to defend individual freedom to sell one's own business, Peckham instead embraced the "property rhetoric of liberty of contract" associated with the faction he previously had opposed. ${ }^{133}$

Peritz suggests that the antitrust cases through 1904 demonstrate how differing commitments to liberty can be related to one another in more than just one way. Sometimes such differing commitments conflict. For example, he argues, the cartel cases displayed a clash between a republicanist commitment to rough competitive equality and a liberal commitment to vigilance against legislative redistribution of property rights. Peritz notes, however, that differing commitments to liberty do not always have to lead to disagreement over specific results, but instead can sometimes coalesce in support of the same outcome. Peritz argues that this happened in the Northern Securities dissents, in which liberty of contract, property rights, and republican concerns for freedom of association all were invoked to oppose the government's attack on the railroad merger in the case. ${ }^{134}$

Even though various commitments to liberty coalesced to oppose condemnation of the Northern Securities merger, says Peritz, a wide impasse still remained between, on the one hand, the commitment to individual liberty expressed by Justice Harlan for himself and three other Justices and, on the other hand, the commitment to individual liberty expressed by the dissenting members of the Court. Harlan's opinion vigorously affirmed the competition rhetoric associated with pointed fears about private economic power and the future of democratic government. The opinions by White and Holmes instead built heavily on a belief in liberty of contract while expressing heightened fears that Harlan's Literalism would severely threaten basic "individual rights of private property and private association." 135

\footnotetext{
133 Id. at $43-44$.

134 Id. at 44.

135 See id. at $44-45$.
} 
b. Lochner v. New York as confirmation of the general factional framework Following this analysis of the 1904 Northern Securities case, Peritz next highlights the famous case of Lochner v. New York, ${ }^{136}$ decided a year later. He does so to illustrate the pervasiveness on the Court of the factional alignments and dynamics he emphasizes in connection with contemporary antitrust cases. Peritz stresses that Lochner posed basic "questions about liberty of contract, economic inequality, and the legitimate scope of government regulation" that were similar to those addressed in Northern Securities. ${ }^{137}$ He notes that when Peckham, writing for the Lochner majority, struck down a maximum hours law for bakers, he strongly echoed the concerns about government power that had been expressed in the dissenting opinions in Northern Securities. Such concerns, says Peritz, led Peckham to emphasize the need to draw a sharp line between legitimate exercises of state police power and infringements on freedom of contract, for fear that otherwise the door would be opened to an ever expanding range of discriminatory government regulation in favor of workers. ${ }^{138}$

Justice Harlan dissented in Lochner. ${ }^{139}$ As he had in Northern Securities, Peritz notes, Harlan displayed greater concern for inequality of economic power than for excessive government regulation. Harlan rejected Peckham's insistence on the formal bargaining equality of the employer and employees. Simultaneously, he deemed legitimate the legislature's finding of actual inequality of bargaining power and the legislature's reliance on numerous studies demonstrating the unhealthiness of prolonged work in bakeries. He therefore found the maximum hours law to be well within the limits of state police power and not an infringement on liberty of contract. ${ }^{140}$

\footnotetext{
136198 U.S. 45 (1905).

137 See PERITZ, supra note 1 , at 45.

138 Id. at 45-46.

139198 U.S. 45, 65-74 (1905) (Harlan, J., dissenting).

140 See PERITZ, supra note 1 , at 47.
} 
In Peritz's view, Northern Securities and Lochner together most clearly revealed "the jurisprudential conflicts . . . in the decade following the turn of the century."141 In each of the two cases, he notes, Harlan's faction found legislative distribution of economic power to be legitimate, while the opposing faction found the same government action to be an improper impairment of freedom of contract. The two factions drew the boundary limit of government regulation in different places because of their strongly contrasting commitments to equality: "While the Harlan faction paid attention to the economic circumstances in each case, both Peckham and White proceeded on an assumption of formal equality." 142

Holmes' dissent in Lochner famously declared that "[g]eneral propositions do not decide concrete cases" 143 and adopted a stance of great, but not unlimited, judicial deference to majoritarian legislative judgments. Peritz argues, however, that Holmes, too, was animated by adherence to a fundamental general principle. In Peritz's view, Holmes' dissent in Northern Securities indicated not only the political economic principle that Holmes deemed fundamental, but also Holmes' willingness to countermand majoritarian legislative action that might gravely undermine it. Peritz declares that while Holmes, like his colleagues, was motivated by commitment to a particular variant of liberty, his most fundamental concern was not freedom of contract. Instead, Holmes cared most about preserving freedom to associate, for both businesses and laborers, in a world otherwise threatened with descent into anarchic, atomistic individualism. ${ }^{144}$

c. The 1911 rule of reason cases: automatically condemned cartels versus personified trusts The Court's substantive due process and antitrust jurisprudence over the next 10 years, Peritz says, largely reflected accommodation between the Court's two

\footnotetext{
141 Id. at 48 .

142 Id.

143198 U.S. at 74-76 (Holmes, J., dissenting).

144 PERITZ, supra note 1 , at $47-48$.
} 
philosophical camps. ${ }^{145}$ Within this setting of general factional accommodation, he relates, the Court in the 1911 cases of Standard Oil Co. v. United States ${ }^{146}$ and United States v. American Tobacco Co. ${ }^{147}$ revisited the issue of the legality of trusts that had so sharply divided the Court in the 1904 Northern Securities case. Now, however, the Justices were able to achieve a nearly unanimous consensus resolution of the problem. ${ }^{148}$

In Peritz's view, the key to this consensus resolution was the Court's creative personification of the Standard Oil Trust, or, in the companion case, the American Tobacco Trust, as merely a single individual, an extension of the leading figure behind the establishment of the trust in question:

By imagining the trust problem as a question of individual conduct rather than an instance of combination, the Court could reconcile competition policy as articulated in the cartel cases with common-law private property rights and with the constitutionalized liberty of contract propounded in Justice White's Northern Securities dissent. 149

In his discussion of the 1911 cases, Peritz reiterates his view that both Sherman's congressional camp and the Court's Literalist faction fundamentally had wanted to preserve rough competitive marketplace equality, out of republicanist concerns for the economic and political dangers thought to be posed by strong disparities in private economic power. In order to preserve such rough equality, says Peritz, the Sherman and Literalist camps endorsed

145 As evidence of the prevalence of factional accommodation, Peritz cites a series of 1908 cases "corroborating the established political economy of class, gender, and race." Id. at 48. The four cases noted are Adair v. United States, 208 U.S. 161 (1908); Loewe v. Lawlor, 208 U.S. 274 (1908); Muller v. Oregon, 208 U.S. 412 (1908); Berea College v. Kentucky, 211 U.S. 45 (1908).
146221 U.S. 1 (1911).
147221 U.S. 106 (1911).
148 See Peritz, supra note 1, at 50.
149 Id. at 50. 
limitation and regulation of property rights when transactions restrained "full and free competition."150

In contrast, Peritz argues, Chief Justice White and other members of the Court's Rule of Reasonist faction fundamentally wanted to protect individual rights of liberty and property. They sympathized with private regulation of competition. Motivated by anxiety over possible government restriction of the basic right to buy, own and sell property, they hoped to block any broad, Literalist application of the Sherman Act that would set limits on the amount of property that could be held or used in interstate commerce. ${ }^{151}$

The liberal rule of reason established in Standard Oil, says Peritz, largely dispensed with old "republicanist concerns about economic power and corporate size." 152 In doing so, however, the newly triumphant rule of reason did not sweepingly approve all trusts. Peritz stresses that White's opinion explicitly acknowledged that the exercise of freedom of trade sometimes could generate unreasonable and illegal restraints of trade. White declared that the common law, and therefore the Sherman Act, recognized that individual liberty of contract could be abused through unnatural behavior going beyond the establishment of "normal and usual" contracts. Two prominent examples of such perceived illegitimate behavior, Peritz notes, were cartelization and the purchase of rivals weakened by a successful campaign of predatory pricing. Because the Court found that the personified trust defendants in Standard Oil and in American Tobacco had engaged in bad conduct that was unreasonable by common law standards, the Court sustained the lower court decrees ordering the dissolution of the two trusts. 153
$150 \quad I d$. at 51.
151 See id.
$152 \quad I d$. at 52.

153 Id. at 52. Peritz neatly summarizes his view of the Court's approach to trust behavior by declaring that the Justices believed that, "[L]ike any person, Rockefeller's Standard Oil was constrained to act 
d. Dr. Miles as a source of further illumination Peritz believes that Justice Charles Evans Hughes' 1911 opinion for the Court in Dr. Miles Medical Co. v. John D. Park \& Sons Co. ${ }^{154}$ illuminates the logic behind the Court's distinction between always unreasonable cartels and only sometimes unreasonable trusts. Peritz suggests a close link between the Court's condemnation of resale price maintenance agreements in Dr. Miles and its already well-established, across-the-board ban on cartel activity. The Court's harsh treatment of both types of conduct, he says, followed a long-established common law view that while a business had the right to set the price at which its agents sell its own property, a business had no right to establish the sales price of someone else's property. Within orthodox contemporary thinking, Peritz argues, condemnation of resale price maintenance agreements, which restrict a buyer's freedom to set prices independently, flowed naturally from condemnation of cartel arrangements, which restrict each participating seller's freedom to set prices independently. 155

Peritz further contends that in Dr. Miles the Rule of Reasonist faction went along with "the Court's Literalist holding that pricefixing is illegal per se"156 because its members, in line with contemporary classical economics in general, did not distinguish between rivalry among sellers operating at the same level in a distribution chain and rivalry between a manufacturer and its retailers. Competition was thought to entail both of these forms of rivalry, says Peritz, so "no one on the Court blinked at citing the cartel cases as precedent." 157

Peritz stresses that the Court's similar handling of both resale price maintenance agreements and cartels contrasted sharply with

reasonably in the exercise of his property rights, his freedom of contract." Id. at 56.

154220 U.S. 373 (1911).

155 PERITZ, supra note 1 , at 53-54.

156 See id. at 54.

157 Id. 
the Court's treatment of each large corporation as merely a single individual in contemplation of law. Although he finds that this was an understandable development in the cultural and economic context of the times, Peritz emphasizes that this difference led to a very important disparity in antitrust status. Cartels and resale price maintenance agreements received automatic condemnation as conspiracies to restrain individual liberty of action. "Individual" trusts, however, did not automatically violate the law, and would only be condemned if they acted "unreasonably."158

e. Factional accommodation facilitated by a formal assumption of equality In short, Peritz finds that the Supreme Court's antitrust and constitutional law jurisprudence through 1911 arose out of confrontations and accommodations between a "Literalist faction" devoted to "a commercial egalitarianism expressed in the rhetorics of industrial liberty and free competition" and a "Rule of Reasonist faction" that was committed to limited government and used freedom of contract rhetoric and energetic judicial review to further that commitment. ${ }^{159}$ In Peritz's view, the key accommodations established between the factions by 1911 were made possible in substantial part by both factions' embrace of a formal assumption of bargaining equality among contracting parties, an assumption that ignored tremendous real-world disparities in wealth and power. ${ }^{160}$

Peritz quotes Justice Mahlon Pitney's 1915 opinion for the Court in Coppage v. Kansas ${ }^{161}$ as a rare candid expression of the sentiments that prompted this important transfactional embrace of a formal assumption of equality. This assumption was embraced, says Peritz, because the Court believed that to do otherwise, and to allow more active government redistribution of wealth and power, either would require abandonment of a regime of private property and contract rights in favor of "public/socialized owner-
158 Id. at $55-56$.
$159 \quad$ Id. at 56.
$160 \quad I d$ at 57.
161236 U.S. 1 (1915). 
ship"162 or, alternatively, might lead to a descent into anarchic social warfare. These fears, says Peritz, strongly propelled a contemporary judicial preoccupation to block government infringement of individual liberty and private property rights. ${ }^{163}$

In Peritz's account, the Court's promulgation of the rule of reason in Standard Oil signified the end of an era. In Peritz's view, the close of this formative period of American antitrust law marked the abandonment of the older political and economic vision that originally had prompted Senator Sherman to urge congressional passage of antitrust legislation:

The ideology of individualism working in Supreme Court jurisprudence and in the writings of the era's elite class no longer projected an image of Jeffersonian yeomanry, of "small dealers and worthy men" threatened by the new economic order. In place of a largely republicanist conception founded in the importance of rough economic equality, a recast ideology took normative content from a liberal conception of individuals as threatened by oppressive and corrupt political majorities. ${ }^{164}$

\section{B. Assessing the factional framework of Progressive Era jurisprudence}

In seeking to place the Supreme Court's early antitrust decisions within the larger context of Progressive Era jurisprudence and political economic thought, Peritz rightly notes that the Justices in this period sometimes disagreed sharply among themselves on fundamental issues of public regulation and private rights. He aptly notes that larger visions of liberty and equality heavily influenced the stance that individual Justices took on the basic issues of competition policy posed in early Sherman Act cases. In addition, he appropriately stresses that basic principles of private property rights, freedom of contract, economic liberty, and political freedom remained recurring, fundamental points of

\footnotetext{
162 PERITZ, supra note 1, at 57.

163 Id.

164 Id. at 58.
} 
reference for Supreme Court Justices in Progressive Era litigation generally.

Peritz's central argument, however, is the more controversial assertion that the Justices throughout this period coalesced into two relatively stable oppositional factions, each of which was composed of members sharing similar basic philosophical commitments that were strongly distinguishable from the general philosophical commitments shared by the members of the opposing group. Peritz's interpretation departs from other scholarly interpretations of Progressive Era jurisprudence ${ }^{165}$ about as strongly as his account of the Sherman Act debates differs from prior assessments of those deliberations. How strongly do the cases he discusses support his contention?

1. THE PHILOSOPHICAL SIGNIFICANCE OF ALTERNATIVE ANTITRUST STANDARDS: THE "EVERY DIRECT RESTRAINT" AND "ONLY UNREASONABLE RESTRAINTS" TESTS It is true, of course, that until 1911, the Justices continued to be divided on the question of the appropriate general formula to govern Sherman Act interpretation. By itself, however, this fact is not sufficient to establish the more fundamental and thoroughgoing philosophical factionalism that Peritz suggests. Continuing disagreement over an appropriate antitrust formula might indicate such a broader and deeper philosophical bifurcation if, first, each of the two alternative formulas was a relatively unambiguous shorthand expression for one of the two contending philosophical agendas Peritz depicts and, second, if each Justice concurring in an antitrust opinion embracing one or another of the two formulas intended thereby to accept the

165 See, e.g., NeIl DuXbury, Patterns of AMERICAN JuRISPRUdence 25-47 (1995); OWen M. Fiss, Troubled Beginnings of the Modern State, 1888-1910 (1993); Morton J. Horwitz, The Transformation of AMERICAN LAW 1870-1960, at 9-31 (1992); HERBERT HoveNKAMP, ENTERPRISE AND AMERICAN LAW 1836-1937, at 93-101, 171-82 (1991); ALFRED H. Kelly et al., The American Constitution: Its Origins and DevelopMENT 386-407, 416-26, 442-47, 453-56 (7th ed. 1991); Michael Les Benedict, Laissez-Faire and Liberty: $A$ Re-Evaluation of the Meaning and Origins of Laissez-Faire Constitutionalism, 3 L. \& HIST. REv. 293 (1985); May, supra note 54, at 262-83, 300-09. 
broader philosophical agenda associated with the particular formula that antitrust opinion embraced. The case record, however, does not strongly indicate that the contending general antitrust standards had clear, fixed meanings; nor does it provide a solid basis for drawing firm conclusions as to the broader philosophical outlook of many of the Justices participating in Progressive Era antitrust adjudication.

Both the "every direct restraint" formula and the "only unreasonable restraints" standard proved, in practice, to be rather elastic. Each could be adapted to a variety of policy orientations. For example, Peritz notes that the "every direct restraint" approach was used in cartel contexts variously to express an overriding "republicanist" concern for the preservation of small dealers and worthy men, ${ }^{166}$ a concern for artificially increased consumer prices stripped of such "republicanist" concerns, ${ }^{167}$ and a liberal preoccupation to protect a seller's individual liberty of business decision-making from the operation of coercive price agreements entered into with other rivals. ${ }^{168}$ Similarly, the "only unreasonable restraints" formula as used by Justice White in Trans-Missouri expressed a case-by-case approach to the legality of cartels ${ }^{169}$ that Peritz finds absent in Chief Justice White's rule of reason opinions in Standard Oil and American Tobacco. ${ }^{170}$ The adaptability of this same general formula of "only unreasonable restraints" permitted different Justices to invoke it to support opposite results in the very same case. ${ }^{171}$ In addition, the two formulas were sufficiently flexible to allow an individual Justice to switch from one

\footnotetext{
166 PERITZ, supra note 1, at 31.

167 Id. at 35.

168 Id. at $43,53,56$.

169 Id. at 30-31.

$170 \quad$ Id. at 52.

171 In Northern Securities, Justice Brewer embraced the "only unreasonable restraints" formula and applied it to condemn the same holding company that Justice White and others, in dissent, approved under the identical "only unreasonable restraints" standard. See 193 U.S. at 360-64 (Brewer, J., concurring), 364-400 (White, J., dissenting).
} 
formula to the other without ever altering his views as to the legality of key types of challenged behavior. ${ }^{172}$

Linking the two general formulas to sharply different philosophical visions is further complicated by the substantial convergence over time in the two standards' practical application. By the turn of the century, despite their continued adherence to differently worded formulas, the initial proponents of each of the two standards, Justices Peckham and White, already had indicated substantial agreement with regard to which arrangements should be prohibited and which allowed. Peritz relates that by this time both Justices had accepted across-the-board condemnation of cartels directly affecting interstate commerce, whether on the ground that all "restraints," in the technical meaning of this word, were banned when they directly affected interstate commerce, or on the ground that all such cartels fell within the category of "unreasonable" restraints. ${ }^{173}$ In addition, by the turn of the century, both Peckham and White also had expressed the view that partial restraints deemed reasonably ancillary to a beneficial main transaction were legitimate under the Sherman Act. ${ }^{174}$ White's 1911 Standard Oil and American Tobacco opinions for the Court can be interpreted as largely formalizing these same results, reached a decade earlier by both White and Peckham, albeit under two separate verbal banners. Substantial consensus as to what the Sherman Act should be read to condemn, notwithstanding disagreement on what general formula should be used as a shorthand for the Act's meaning, also seemingly is indicated by Peritz's observation that

172 Justice Brewer initially had embraced Peckham's "every direct restraint" approach in the railroad cartel cases. In 1904, in Northern Securities, he switched to the "only unreasonable restraints" formula. He immediately used it, however, as a vehicle both to continue his earlier condemnation of all cartels directly affecting interstate commerce, regardiess of the "reasonableness" of their prices, and to condemn the holding company established to effect the giant railroad combination challenged in Northern Securities. See 193 U.S. 197, 360-64 (Brewer, J., concurring).

173 See PERITZ, supra note 1, at 37.

174 See, e.g., May, supra note 54, at 308. 
the Northern Securities decision "was the last of only three antitrust cases (out of about two dozen) that divided the Court in antitrust's 'formative era' between 1890 and 1911."175

2. THE LIMITED EVIDENCE AS TO PARTICULAR JURISTS' MOTIVATIONS AND OUTLOOK Determination of the broader philosophical views of the various individual Justices is complicated partly by the number of changes in personnel that occurred on the Court between the time of the first railroad cartel cases and the 1911 promulgation of the "classical" rule of reason. ${ }^{176}$ Direct evidence concerning the ideological or philosophical outlook animating the votes of particular newer and older members in specific antitrust cases frequently is rather limited, especially if the particular Justice did not offer a separate written opinion that clearly indicated whether he did or did not agree with everything expressed in another Justice's opinion. In a given instance, a particular Justice's concurrence, for example, might have resulted alternatively from fervent adherence to the philosophical position articulated in another Justice's opinion or simply from a felt duty to follow established precedent even though at odds with the particular Justice's own policy preferences.

Peritz undoubtedly is right in contending that important differences of perspective persisted among the Justices, both in general and with regard to antitrust law in particular, even after ongoing unanimity was established in cartel cases by the turn of the century. Peritz's discussion of the Court's 1904 and 1905 decisions in Northern Securities and Lochner makes this clear. Those two

175 PERITZ, supra note 1 , at 28.

176 The Court that decided Trans-Missouri in 1897 was composed of Chief Justice Fuller and Justices Brewer, Brown, Field, Gray, Harlan, Peckham, Shiras, and White. The High Court that considered the 1904 Northern Securities case consisted of Chief Justice Fuller and Justices Brewer, Brown, Day, Harlan, Holmes, McKenna, Peckham, and White. The members of the Court voting in the 1911 Standard Oil and American Tobacco cases were Chief Justice White and Justices Day, Harlan, Holmes, Hughes, Lamar, Lurton, McKenna, and Van Devanter. See THE OXFORD COMPANION, supra note 124, at 985 . 
cases and the later 1911 rule of reason decisions, however, ultimately do not seem to support Peritz's specific factionalization thesis nearly as strongly as he suggests they do.

3. THE COMPLEXITIES OF NORTHERN SECURITIES Northern Securities presented issues of federal Commerce Clause power, government authority to regulate property sale and acquisition, and the economic, social, and political consequences of tighter versus looser forms of combination that differed substantially from the issues posed by the earlier railroad cartel and Addyston Pipe cases. Conceivably, the differing voting alignment of Justices in Northern Securities as compared with earlier antitrust cases may simply have reflected various Justices' individual assessments of such new issues. Peritz, however, explains the case instead as a sudden factional membership crisis within a still continuing context of contention between a Literalist and a Rule of Reasonist camp.

Peritz reports that Justice Harlan and the Justices who concurred in his opinion adhered to the old Literalist camp creed in its original, pristine form. He finds, however, that two of the key original founders of that camp, Justices Peckham and Brewer, now "abandon[ed] their Literalist colleagues for the Rule of Reasonist camp[.]"177 These apostate Literalists, however, did not immediately become the chief spokesmen for rule of reasonist perspectives. Instead, Peritz notes, the chief proponents of such perspectives in Northern Securities were the authors of the two written dissenting opinions in the case, Justices White and Holmes.

All of the Justices except for Justice Harlan and those concurring in his opinion can be said to have rejected the verbal formula of "every" restraint. For reasons already noted, however, this does not necessarily demonstrate a strong continuing pattern of more general ideological bifurcation on the Court, with a number of Justices strongly sharing one particular set of basic philosophical commitments under the banner of "every" direct restraint of trade while the remaining members strongly shared a distinctly different set of basic philosophical commitments under the alternative

177 See PERITZ, supra note 1 , at 43. 
banner of "only unreasonable" restraints. More detailed examination of the antitrust thinking of the individual Justices participating in the Northern Securities decision seems to complicate rather than strongly confirm the specific factional pattern Peritz suggests.

Two of the Justices concurring with Justice Harlan, Justices Day and McKenna, had not participated in the early railroad cases in which the "every" and "only unreasonable" restraints standards had been first proposed and discussed. In separately concurring in Northern Securities, Justice Brewer did not obviously alter his outlook on anything more than what set of words best would express his ostensibly unaltered, basic philosophic disposition on antitrust issues. Brewer explicitly reaffirmed his original position on cartels. Simultaneously, he expressly condemned the holding company arrangement that both White and Holmes sought to uphold on grounds of fundamental commitment to private property rights and freedom of association. At most, it would seem, Brewer's concurring opinion might support a claim that, far from defecting, Brewer largely remained comfortable in his old camp home but now wished he could steal the other camp's flag to fly over his own ideological position. ${ }^{178}$

Was Peckham an ideological deserter? ${ }^{179}$ The claim seems premised on a belief that the nature of contemporary thought

178 Peritz stresses not only Brewer's adoption of the "only unreasonable restraints" formula in Northern Securities, but also his affirmation of each individual's right "to manage his own property and determine the place and manner of its investment." 193 U.S. at 361 (Brewer, J., concurring). All of the Justices writing opinions in Northern Securities, however, expressed agreement with this general principle. Harlan for the plurality and Brewer, separately concurring, found no impairment of this principle in their condemnation of the holding company challenged in the case. They saw the holding company as the instrument of an unlawful combination among individual shareholders which, they believed, was not protected by the acknowledged right of a single individual acting independently to buy and sell whatever and how much he or she might choose. See 193 U.S. at 335, 354 (Harlan, J., for the plurality), 362 (Brewer, J., concurring).

179 See PERIT, supra note 1, at 43 (analyzing Peckham's "desertion to the Rule of Reasonist faction"). 
heavily forced jurists not simply to come to terms with antitrust questions on an issue-by-issue basis, but continually to choose between two different, particular sets of interrelated positions. In this conception, the Literalist set offered a sweeping condemnation of cartels, strong support for competition as the rule of trade, and pointed concern over the possible dangers of augmented private economic power. The posited Rule of Reasonist package, on the other hand, offered forceful affirmation of the importance of private property rights, freedom of contract and freedom of association, a tempered commitment to competition as the rule of trade, and pointed concern to prevent the onset of either statism or anarchic social warfare.

With such a starting premise, one can conclude that Peckham "abandoned" not just the slogan but the "ideological camp" of Literalism because, while his earlier positions in the cartel cases were drawn from the Literalist set, his concurrence in the dissenting opinions of Justices White and Holmes in the holding company stock acquisition case of Northern Securities indicated strong belief in the protection of private property rights, freedom of contract, and freedom of association.

It seems quite possible, however, that Peckham never actually changed his basic philosophical outlook during his years on the high court. Peritz cites no instance in which Peckham ever changed his mind or his vote on the issues he actually addressed as "leader of the Literalists" in the earlier cartel cases-specifically, the unavailability of any reasonable price or ruinous competition defense for cartels, the undesirability of the decline of small dealers and worthy men, or the harmfulness of increased prices achieved through cartel activity. From the day he joined the Court, Peckham may well have been strongly inclined to hold the views he expressed in the cartel cases right alongside strong concerns for excessive government regulation of other, more "ordinary" or "natural" types of contracting activity that he might have thought to be sharply distinguishable from cartel agreements. He also may well have had precisely the same inclinations on the day he died. In short, Peckham may only have been reacting to the difference in the specific issues presented in the early cartel cases 
and in Northern Securities. In taking the positions he did in these cases, he may have done no more than to express separate aspects of a single overall general outlook that he maintained essentially intact throughout his tenure on the Court. ${ }^{180}$

What about Holmes? Given the distinctiveness of his thought, assimilating Holmes to either half of a perceived philosophical bifurcation among the other Justices of the High Court would seem a formidable task. Peritz associates Holmes with the Rule of Reasonist faction ${ }^{181}$ because of his dissent from Harlan's Literalist condemnation of the combination of two major railroads through the holding company challenged in Northern Securities. In placing Holmes in the Rule of Reasonist camp, Peritz stresses Holmes' expressed concern to uphold private property rights, liberty of contract, and the freedom to establish reasonable combinations. He also emphasizes Holmes' hostility to any extreme interpretation of the Sherman Act that might insist upon the disintegration of society into atomistic warfare. It is more than a little

180 His concurrence without separate written opinion in the dissenting opinions of White and Holmes, of course, might well be taken to indicate at least a new acceptance of the "only unreasonable" restraints terminology for Sherman Act interpretation. This does not necessarily mean, however, that Peckham in 1904 hoped for any different results in antitrust cases than he ever might have desired before. Starting with his very first antitrust opinions, Peckham had made it clear that by "every" he did not mean "every," or to put it another way, that "restraint of trade" was a technical term that did not actually include everything that might be alleged to come within the phrase. See United States v. TransMissouri Freight Ass'n, 166 U.S. 290, 329 (1897); United States v. Joint Traffic Ass'n, 171 U.S. 505, 568 (1898). The facts of Northern Securities may have given him new concern that his earlier words might be misinterpreted badly. Brewer, indeed, in that very case expressly justified his turn to the formula of "only unreasonable" restraints on the ground that he now perceived too great a danger of misinterpretation in the "every" restraint test he previously had embraced along with Peckham. See 193 U.S. at 364. In doing so, however, Brewer made it clear that adoption of the terminology that Justice White had first urged did not signify or require abandonment of any of the substantive positions he and Peckham previously had taken in earlier antitrust cases. See $i d$. at 360-61.

181 See, e.g., PerITz, supra note 1, at 27. 
problematic, however, to see Justices Holmes, Peckham, White, and Brewer and Chief Justice Fuller as strong philosophical compatriots as of 1904 in ongoing, fundamental contention with an opposing ideological camp staffed by Justices Harlan, Brown, Day, and McKenna. This is especially true if the two factions are to be identified by a distinctive similarity in their members' orientations toward public regulation of property rights, liberty of contract, and freedom of association.

4. NORTHERN SECURITIES IN THE LIGHT OF LOCHNER The problem is heightened rather than lessened by Peritz's reference to Lochner and the larger pattern of contemporary Supreme Court jurisprudence. Peritz tries hard to picture the 1905 opinions in Lochner as a confirmation and continuing reflection of the factional split he finds evident in the 1904 Northern Securities opinions. Peritz declares that the two cases "raised similar questions about liberty of contract, economic inequality, and the legitimate scope of government regulation." 182 In both cases, he notes, one group of Justices found that majoritarian government regulation had exceeded its legitimate scope and had transgressed freedom of contract. In addition, he argues, in each of the cases, the two opposing factions were animated by conflicting general visions of political economy and "sharply differing commitments to equality." Specifically, "While the Harlan faction paid attention to the economic circumstances in each case, both Peckham and White proceeded on an assumption of formal equality." 183

Peritz also finds continuity between the two cases in the philosophical, and therefore factional, orientation of Holmes in particular. In both cases, he notes, Holmes expressed a belief in only limited majoritarianism and a conviction that certain fundamental principles set boundaries for government regulation. For Holmes, Peritz stresses, a fundamental principle limiting regulatory expressions of dominant public opinion was the principle of liberty to associate and form social and commercial combinations.

\footnotetext{
$182 I d$. at 45.

183 Id. at 48.
} 
Taken together, says Peritz, the various opinions in Northern Securities and Lochner most clearly displayed the contemporary "rhetorical confrontations between Supreme Court factions espousing free competition (or, to their opposition, social conflict) and freedom of contract (or, to their opposition, antimajoritarianism)."184

If Northern Securities and Lochner together can be interpreted as strong, clear evidence of the continuation of a fundamental philosophical split on the Court expressed through an ongoing confrontation between a free competition faction and a freedom of contract faction, one might wonder what it would take to cast serious doubt on such a view. How strong a picture of factional continuity and internal camp solidarity do those two cases in fact present? The Justices that Peritz includes in the Literalist faction in the 1904 Northern Securities case are: Harlan, Brown, Day, and McKenna. Peritz locates all the remaining Justices in the Rule of Reasonist camp, namely: Justices White, Holmes, Brewer, and Peckham, and Chief Justice Fuller. In Lochner a year later, however, Peritz finds in the Literalist camp Justices Harlan, Day, White, and Holmes (two Northern Securities Literalists and two Northern Securities Rule of Reasonists). Simultaneously, he finds that by 1905, the Rule of Reasonist camp had come to be inhabited by Chief Justice Fuller and Justices Peckham, Brewer, Brown, and McKenna (three Northern Securities Rule of Reasonists and two Northern Securities Literalists).

5. ATTITUDES ABOUT CARTELS, MAJORITARIAN REGULATION, AND ASSUMPTIONS OF FORMAL EQUALITY AS CRITERIA FOR FACTIONAL IDENTIFICATION The thesis that until 1911 the Progressive Era Court was philosophically split into a free competition faction and its freedom of contract opponent can be explored further by focusing at greater length on three of the key dimensions of factional identification that Peritz emphasizes, specifically, the various Justices' views on cartels, majoritarian regulation, and assumptions of formal equality.

$184 I d$. 
First, consider the evolving pattern of High Court thinking about cartels. Peritz notes what at first might seem a strangely rapid coalescence in the various Justices' approach to cartels and offers a possible explanation for at least the first appearance of Supreme Court unanimity on this issue. His explanation for the continuation of such unanimity over the next two decades despite the later absence of the special circumstances that he claims first made unanimity possible, however, seems to leave open significant questions that might usefully be explored further in the future. ${ }^{185}$

185 Peritz suggests that during most of the 1890 s, fundamental philosophical disagreement over the appropriate treatment of cartels was central to the distinction between the two factions. See id. at 30-36. He notes that as early as the 1899 case of Addyston Pipe, the two factions unanimously could embrace Justice Peckham's opinion for the Court that condemned the bid rigging arrangement challenged in the case. $I d$. at 36. This, however, is explained not as an absence of continued strong factional thinking, but instead as an indication of silent accommodation among previously established factions that remained as alive as ever. The special facts of Addyston Pipe, involving a bid rigging scheme that was deemed to be fraudulent and that had established prices that were deemed to be unreasonable in fact, he says, allowed both factions to join in the result of the case. Id. at 36-37. Peritz notes, however, that in almost all cartel cases thereafter the Court continued to condemn cartels unanimously, even in the absence of the special facts that had allowed agreement in Addyston Pipe. See id. at 37-38. This would seem to leave unanswered the question whether White and other Justices who initially wanted a reasonable price defense went along in later cases because they had changed their policy preference or merely because they deferred to established precedent. If White and other Rule of Reasonists completely reversed their basic philosophical outlook on cartels in such a short space of time, it seems harder to conceive of the High Court as divided into two factions firmly grounded in two fundamentally different sets of philosophical commitments. If, conversely, by the turn of the century, the members of the Rule of Reasonist faction concurred in the Court's rejection of any reasonable price or ruinous competition defense merely out of deference to precedent, then it seems problematic to include either Brewer or Holmes in that ideological camp as of 1904. This is because both Brewer and Holmes in their Northern Securities opinions pointedly affirmed their philosophical agreement with the Court's Trans-Missouri and Joint Traffic precedents. See 193 U.S, 197, 360 (Brewer, J., concurring), 405 (Holmes, J., dissenting). 
Second, consider the implications of relying on comparative levels of deference to majoritarian regulation as a basis for assigning Justices to one or another of the two basic factions Peritz pictures. The Justices repeatedly did disagree when reviewing legislation challenged as an infringement of private property rights or liberty of contract. It seems very difficult, however, to characterize Justices Peckham and Brewer, either before or after 1904, as falling within the half of the High Court bench that was comparatively less concerned with the protection of private property rights or liberty of contract in general. ${ }^{186}$ As a result, even though Peckham and Brewer until 1904 embraced the Literalist antitrust standard of "every direct restraint on interstate commerce" it is problematic to associate them strongly and exclusively with a philosophical faction defined heavily on the basis of a comparatively less fervent commitment to freedom of contract and private property rights.

Reliance on relative wariness toward majoritarian economic regulation complicates assignment of Justice White's rhetorical residency as well. If factional membership is seen as long-lived rather than merely a matter of the voting alignment in a single case, it becomes necessary to explain not only White's stance in various antitrust cases, but also why he dissented in Lochner and thus aligned himself with what Peritz terms the "Harlan faction" in opposition to the Peckham-led majority that struck down the maximum hours law for New York bakers. It also becomes necessary to explain why White found constitutional the regulatory measures challenged in a number of other major cases decided by a divided Court. ${ }^{187}$

186 See, e.g., Fiss, supra note 165, at 32-33, 134; Paul Kens, Peckham, Rufus Wheeler, in ThE OXFord COMPANION, supra note 124, at 626-27; May, supra note 54, at 303-04. Brewer and Peckham, for example, were the only two Justices who dissented from the Court's approval of a maximum hours law for miners in Holden v. Hardy, 169 U.S. 366, 398 (1898).

187 See Holden v. Hardy, 169 U.S. 366 (1898); Champion v. Ames, 188 U.S. 321 (1903); McCray v. United States, 195 U.S. 27 (1904); Hammond Packing Co. v. Arkansas, 212 U.S. 322 (1909). Cf. also Pollock v. Farmers' Loan \& Trust Co., 158 U.S. 601, 706-15 (1895) (White, J., dissenting). 
Holmes, too, seems to resist easy classification within Peritz's suggested general factional framework if deference to majoritarianism is emphasized. It clearly is true that everyone, including Holmes, believed that there were constitutional limits on the power of majoritarian legislatures. In addition, Holmes' dissent in Northern Securities did strongly express wariness of excessive federal regulation and a quite sympathetic view toward the expansion of combination activity in society. At the same time, however, of everyone on the Court, Holmes in general advocated the stance of greatest judicial deference to legislative action. It thus might have surprised him to be considered, as of 1904-1905, a leading philosophical compatriot of Justice Peckham, with whom he disagreed so sharply in Lochner itself.

What of the third noted dimension of demarcation, i.e., the Justices' comparative receptivity to an assumption of formal equality? Use of this criterion similarly does not consistently support the factional identifications Peritz assigns to various Justices. For example, in Lochner itself, both Holmes and White rejected an assumption of formal equality. At least by itself, this would weigh in favor of including both White and Holmes in the Literalist camp rather than in the Rule of Reasonist camp because, in Peritz's account, it was the former and not the latter camp that was relatively more attentive to economic reality and less inclined to embrace a judicial assumption of formal equality, at least until 1911.

6. THE 1911 RULE OF REASON CASES What, then, of the crowning events of formative era antitrust jurisprudence, the 1911 opinions establishing a new rule of reason in Standard Oil and American Tobacco? Peritz declares that these decisions represented the final factional accommodation that brought this first great era of American antitrust law to a close. He argues that this accommodation consisted of several key, interrelated elements. On the one hand, the Court abandoned earlier republicanist concerns with economic power and corporate size and creatively indicated that in contemplation of law each giant trust or corporation was to be treated as merely a single individual rather than a combination. On the other hand, the Court continued to condemn all cartels directly affecting 
interstate commerce and declared trusts to be in violation of the Sherman Act when they engaged in unfair and improper forms of business rivalry. Peritz contends that this 1911 accommodation between rhetorical camps was made possible in large part because by 1911 both factions finally had come to embrace a formal assumption of bargaining equality among participants in economic life, an assumption that ignored the great disparities in wealth and power that actually prevailed in the economy.

How persuasive is this view of the origin, meaning, and significance of the rule of reason announced in Standard Oil and American Tobacco? First, there is the question of the asserted cross-factional abandonment of republicanist concerns with economic power and corporate size. It is true that the decrees in these two cases did not effectively dissipate the defendants' market power. Nevertheless, it seems a little strong to conclude that, rhetorically, the Court largely discarded older concerns about economic power and the expanding dimensions of business organization. A number of passages in Chief Justice White's opinion for the Court in Standard Oil seem to indicate significant continuing concerns for overweening economic power and corporate size. White emphasized, for instance, the "vast amount of property and the possibilities for far-reaching control"188 that the defendants had amassed by the 1880 s and the disturbing fact that in later years Standard Oil of New Jersey acquired "an enlarged and more perfect sway and control over the trade and commerce in petroleum and its products." 189 Concern for economic power and corporate size also seems to be suggested in a passage a few pages later in White's opinion, in which White stressed that various activities challenged in the case "necessarily involved the intent to drive others from the field and to exclude them from their right to trade, and thus accomplish the mastery which was the end in view." 190

188221 U.S. at 70.

189 Id. at 71.

$190 \quad I d$. at 76. 
Peritz's view may be that while such passages might suggest a concern with economic power and corporate size they do not suggest a specifically republicanist concern linked to the particular political as well as economic fears that he believes earlier had animated Senator Sherman and the Court's Literalists. In recent years, historians have engaged in extensive scholarly debate over the appropriate usage of the terms "republican" and "liberal" and the extent to which various persons and ideas convincingly can be identified exclusively with one or the other of these two "rhetorics" or languages of discourse. ${ }^{191}$ Peritz does not discuss this literature at any length or relate in much detail why, for example, Peckham's early expression of concern for the loss of small dealers and worthy men could not also have been embraced by contemporaries with a "classically liberal" outlook premised on a vision of unconcentrated markets driven by the active presence of many such roughly equal small dealers and worthy men. Similarly, he does not explain directly why the passages just quoted from White's opinion in Standard Oil necessarily indicate the absence of any lingering republicanist sensibilities on the Court. In any event, whatever one infers about White's own views, the direct evidence seems somewhat limited to draw strong final conclusions regarding the extent to which various other Justices had or had not fully abandoned any significant trace of older republicanist concerns over economic power or corporate size by 1911.

In asserting that the Court discarded such concerns in the 1911 rule of reason cases, Peritz relies heavily on the Court's personification of corporations and trusts. One of Peritz's leading criticisms of competition policy from the 1890s until the New Deal is that the Supreme Court adopted a nonuniform antitrust approach to combinations by treating each large trust and each large corporation as merely a single individual in contemplation

191 See, e.g., JoYce APPLEBy, LIBERALISM AND REPUBLICANISM IN THE HistoRiCAL IMAGINATION (1992); ISAAC KRAMNICK, REPUBLICANISM \& BoURGEOIS RADICALISM 260-88 (1990); Daniel T. Rodgers, Republicanism: The Career of a Concept, 79 J. AM. Hist. 11 (1992); Gordon Wood, The Virtues and the Interests, NEw REPUBLIC, Feb. 11, 1991, at 32. 
of law. In Standard Oil, he finds, the Court embraced per se condemnation of price-fixing combinations ${ }^{192}$ but treated a huge trust as merely a single individual, a classification that meant that a Sherman Act violation would be found only if the trust engaged in abusive forms of business rivalry. Peritz cites to very little in Chief Justice White's opinions in Standard Oil and American Tobacco that directly bears on the treatment of a large corporation or trust as a single individual. Instead, to support his point, Peritz chiefly points to indications of the growing personification of corporations and trusts, but not cartels, within popular culture, the Court's increasing treatment of corporations as persons in various nonantitrust contexts in the late 19 th and early 20 th centuries, and certain passages from White's dissenting opinion in Northern Securities.

The list of contemporary factors supporting the treatment of a corporation as a single individual for federal antitrust purposes readily could be expanded further. One might note, for example, section 8 of the Sherman Act itself as passed in $1890 .{ }^{193}$ It is not sufficient, however, to find that at the time of the 1911 rule of reason cases there was an increasing legal and cultural tendency to personify corporations.

Conceding that this general tendency existed, it nevertheless remains difficult to find in either Standard Oil or American Tobacco itself an underlying judicial premise that the Court was facing "a question of individual conduct rather than an instance of combination." 194 Neither opinion so characterized the record

192 See PERITZ, supra note 1 , at 52.

193 Section 8 of the Act declared:

That the word "person" or "persons," wherever used in this act shall be deemed to include corporations and associations existing under or authorized by the laws of either the United States, the laws of any of the Territories, the laws of any State, or the laws of any foreign country.

Sherman Antitrust Act, ch. 647, 26 Stat. 210 (1890) (codified as amended at 15 U.S.C. $\$ 7$ (1994)).

194 PERITZ, supra note 1 , at 50. 
before the Court. Indeed, in both cases the Court heavily and explicitly stressed illegitimate combination activity as the basis for finding a violation of the Sherman Act. ${ }^{195}$

Finally, what of Peritz's contention that the unanimity in the 1911 rule of reason cases can be attributed substantially to a cross-factional willingness formally to assume equality among parties in economic life? Even though Peritz finds that in Lochner the Court's two factions differed sharply in their willingness to accept an assumption of formal equality, he concludes that 6 years later the two factions were able to reach a landmark general accommodation in substantial part because both factions by then had come to embrace exactly this assumption. As evidence for this change of heart, Peritz does not cite to developments through 1911, but instead points primarily to Justice Mahlon Pitney's 1915 opinion in Coppage, which delared unconstitutional a state statute banning "yellow dog" contracts. As Peritz notes, Pitney's opinion is one of the most striking contemporary Supreme Court statements in favor of a formal legal assumption of equality among contracting parties. Pitney's opinion, however, seems an odd one to pick to support a claim that, by 1911 , both factions on the Court embraced an assumption of formal equality. Pitney did not join the High Court bench until 1912. Of the seven Justices who were on the Court in 1911 and still on the Court in 1915, four joined Pitney's opinion ${ }^{196}$ while the other three strongly dissented. ${ }^{197}$

195 See Standard Oil Co. v. United States, 221 U.S. 1, 70-77 (1911); United States v. American Tobacco Co., 221 U.S. 106, 181-84 (1911).

196 These were Justices Lamar, McKenna, and Van Devanter and Chief Justice White.

197 Justices Holmes and Day each wrote a dissenting opinion. 236 U.S. 1, 26-27 (Holmes, J., dissenting); 27-42 (Day, J., dissenting). Justice Charles Evans Hughes concurred in Day's opinion. Since the time that the decisions in Standard Oil and American Tobacco were announced, Justice Harlan had been replaced by Justice Pitney and Justice Lurton had been replaced by Justice McReynolds. See THE OXFORD COMPANION, supra note 124 , at 985. 
7. COMPETITION POLICY IN THE SUPREME COURT THROUGH 1911 Peritz's thought-provoking discussion of the early cases significantly advances his overarching argument that the history of American competition policy since 1890 has not been simply a "progression of better economic or political ideas gaining consensus."198 It also substantiates his claim that the Justices in this period centrally were concerned with a broader range of basic values than simply the norm of robust competition. Peritz also presents considerable evidence that jurisprudential outlooks and doctrines concerning competition, property rights, efficiency, liberty, and equality historically have been "contestable social and political choices, [rather than] products of (super)natural, historical, economic, or logical necessity."199 As in his discussion of the Sherman Act debates, however, Peritz at times seems a bit too determined to fit diverse understandings and applications of these basic principles within a particular pattern and structure of sharp, ongoing factional division that often seems at odds with the historical record.

III. The prelude to postclassical economics and the New Deal: cooperative economic competition and threatening political rivalry

\section{A. From Standard Oil to the New Deal}

After addressing rhetorical rivalry in the Sherman Act debates and early case law, Peritz next turns to developments during the turbulent two decades following the 1911 rule of reason cases. He focuses particularly on the consequences of World War I mobilization, expanded state and federal regulation, increasing trade associationalism, the ongoing struggles of organized labor, and conflicts over free speech rights. Peritz concludes that these developments called into question the liberal political economic assumption that antagonistic competition was the natural condition of relations between individual citizens and majoritarian

\footnotetext{
198 PERITZ, supra note 1 , at 5.

Id. at 8 .
} 
government, between commercial rivals, and between workers and their employers. As had been true through 1911, says Peritz, "competition and property rhetorics, inspired by commitments to liberty and equality, would shape the policy arguments posed to resolve such questions." 200

Peritz relates that in the wake of the Court's 1911 antitrust opinions, an American public identifying with the earlier image of beleaguered "small dealers and worthy men" feared that most trusts would be approved under a rule of reason that only condemned business size or economic power if it was conjoined with bad acts. ${ }^{201}$ The 1914 Clayton and Federal Trade Commission Acts passed in response to such concerns established new prohibitions that specifically targeted threats to competition. Peritz notes, however, that this legislative response did not simply resuscitate the commitment to "full and free competition" originally embraced by the Sherman and Literalist factions. By 1914, he relates, the image of competition itself was changing to reflect new "open competition" ideas that promoted cooperation among rivals as a way to generate a superior form of competition. ${ }^{202}$

Peritz notes that by 1914 the Supreme Court already had begun an extended period of strongly conservative jurisprudence. Animated by the commitment to freedom of contract that earlier prompted the Court's opinions in both Lochner and Standard Oil, "the Supreme Court under Chief Justices White and Taft was unrelenting in its protection of commercial activity from legislative 'intervention'."203 This pattern, says Peritz, reflected a judicial belief that "free competition meant freedom from government administration, but not freedom from concerted private administration of markets."204 Peritz focuses particularly on four aspects

\footnotetext{
$200 \quad$ Id. at 58.

201 Id. at 61.

202 Id. at 64-66.

203 Id. at 66.

204 Id. Peritz cites as examples of the Supreme Court majority's hostility to congressional economic regulation the Court's 1920 decisions in United States v. U.S. Steel Corp., 251 U.S. 417 (1920) and FTC v. Gratz,
} 
of the Court's jurisprudence between 1911 and 1933: (1) its condemnation of public and private price fixing; (2) its embrace of a new formulation of the rule of reason and its growing acceptance of trade association activity; (3) its hostility to labor associations; and (4) its differing treatment of political and commercial speech.

1. HOSTILITY TO PUBLIC AND PRIVATE PRICE FIXING During the 1920 s, state regulation of rates repeatedly posed the important issue of government power to limit an individual's right to establish the sales price for his or her own property. The Supreme Court consistently rejected state power to regulate the rates of businesses outside a narrowly defined category of businesses "affected with a public interest," a category which had come to include little more than utilities and railroads. ${ }^{205}$ Peritz notes that

253 U.S. 421 (1920). Peritz notes that in U.S. Steel, Justice McKenna, for the Court, departed from freedom-of-contract-based classical economics. Instead, says Peritz, he embraced rising neoclassical economic views that treated as competitive "anything short of complete market control." PERITZ, supra note 1, at 67. "Because U.S. Steel controlled only 80 to 90 percent of its major product markets," Peritz notes, "it had not achieved, in McKenna's estimation, monopoly power." Id. Simultaneously, U.S. Steel reaffirmed Standard Oil's doctrine that, in any event, tremendous corporate size and industry domination were not enough by themselves to constitute a violation of the Sherman Act. Justice McKenna's opinion also reflected a displacement of classical by neoclassical, market-based rather than freedom-of-contract-based, economics in its treatment of the informal cooperation that had developed between U.S. Steel and its rivals. McKenna approved this behavior on the ground that it helped to stabilize a financially risky market. Id.

Justice McReynolds' 1920 opinion for the Court in FTC v. Gratz, says Peritz, expressed the Court's very different level of tolerance for public, as opposed to private, market regulation. In that case, the Court denied the Federal Trade Commission authority under the Federal Trade Commission statute to identify and enjoin as "unfair methods of competition" any acts going beyond conduct already prohibited under judicially created common law, even where an act manifestly had been considered an unfair method of competition by the Congress that passed the Clayton and Federal Trade Commission Acts. Id. at 67-68.

20s Peritz, supra note 1 , at 72 . Peritz notes that a divided Court refused, for example, to uphold either New York's regulation of prices for theater ticket agents or Tennessee's effort to regulate retail gasoline prices. Id. at 73-75. 
the Justices disagreed sharply on whether this judicial determination that "public price-fixing was illegal per se" was consistent with the Court's 1927 opinion in United States v. Trenton Potteries Co., ${ }^{206}$ finding "private price fixing illegal regardless of intent and competitive effect." Justice Sutherland and other conservative members of the Court believed that "all naked price-fixing, whether public or private, was unacceptable, because such associations coerced individuals. Neither political majorities nor dominant cartels were permitted to trample individual liberty of contract, whose purest practice was the right to set sales prices."207 Other Justices, however, such as Justice Harlan Fiske Stone, the author of the Court's Trenton Potteries opinion, analogized public price setting to the operation of competitive markets rather than to the operation of private cartels. Instead of reflecting a cartel-like intent to increase prices above fair, competitive levels and to augment economic power, public rate setting stepped in to reestablish prices that were fair to both producers and consumers when the normal regulative force of competition had been weakened or had proven unworkable in particular circumstances. 208

2. A NEW RULE OF REASON AND GROWING ACCEPTANCE OF TRADE Associations Spurred by the War Industries Board's success in organizing wartime production and distribution, by Herbert Hoover's promotional efforts as Secretary of Commerce, and by the related writings of private enthusiasts for such a new form of "cooperative competition," trade associations proliferated by the thousands during the 1920s. In part, such associations represented a desire to improve economic conditions through exchanges of information that would lead to market stabilization and thereby avoid both ruinous competition and market monopolization. ${ }^{209}$

Peritz notes that a number of developments in this period forced reconsideration of the relationships among competition,

\footnotetext{
206273 U.S. 392 (1927).

207 PERITZ, supra note 1 , at 74.

208 Id. at 74-75.

209 Id. at $75-78$.
} 
private property, individual liberty, and economic inequality. ${ }^{210}$ Wartime mobilization, postwar trade associationalism and major new theoretical developments all called into question older classical liberal conceptions of individualistic market rivalry. For example, recently developed neoclassical economic perspectives, says Peritz, did not emphasize market competition as the product of individual exercise of liberty of contract, but instead analyzed competition functionally with regard to particular market settings. ${ }^{211}$

An even newer theoretical challenge to such classical visions appeared in Justice Brandeis' 1918 opinion for the Court in Board of Trade of Chicago v. United States. 212 The "classical" rule of reason announced in Standard Oil, says Peritz, pointed to a determination of individual case results based on a loosely deductive application of the implications of the fundamental general principle of liberty of contract. In contrast, Brandeis' "postclassical" rule of reason pointed to a determination of legality or illegality in particular cases based on a loosely inductive examination of the particular facts of each case, in an effort to determine the competitive effects of challenged practices. ${ }^{213}$

After the First World War, the Department of Justice brought a series of cases challenging trade association activities, analogizing them to the cartels condemned by the Supreme Court in earlier cases. Justice John H. Clarke's 1921 opinion for the Court in American Column and Lumber Co. v. United States, ${ }^{214}$ says Peritz, reflected the Supreme Court's early suspicion of trade associations in general. Clarke inferred that the particular information exchange program challenged in that case involved an agreement to fix prices, accomplished through the coordinating efforts of the Association's Manager of Statistics and "the disposition of men

\footnotetext{
$210 \quad$ Id. at 78.

$211 \quad$ Id. at 79.

212246 U.S. 231 (1918).

213 PeRITZ, supra note 1 , at 80.

214257 U.S. 377 (1921).
} 
'to follow their most intelligent competitors'."215 In these early cases, a majority of the Justices generally perceived not the promotion of more intelligent and better informed individual competitive decision making, but instead another variety of anticompetitive price fixing. 216

The Court's 1925 opinion in Maple Flooring Manufacturers Association v. United States ${ }^{217}$ ushered in a dramatically altered approach to trade association data dissemination. Written by Justice Harlan Fiske Stone, the Court's opinion strongly endorsed information exchanges within trade associations, as long as they did not extend to explicit price fixing. ${ }^{218}$ Adopting a "Brandeisian rule of reason" focusing on the particular facts of each individual case, the Court now demanded clear proof of market power, bad purpose and anticompetitive effects in order to establish that a particular information exchange program violated the Sherman Act. In the view of the Court majority, Peritz notes, the absence of an explicit agreement on price indicated an absence of coercion or restriction of individual decision making. The Court found neither bad purpose nor anticompetitive effect in the information exchange program in Maple Flooring. Instead, the majority found

215 PerITZ, supra note 1 , at 83 (quoting American Column and Lumber, 257 U.S. at 399). Both Holmes and Brandeis dissented. Peritz notes that, surprisingly in light of his Chicago Board of Trade opinion, Brandeis echoed White's earlier emphasis on the restriction of individual private property rights and freedom of contracting as the test of legality and declared it inappropriate to judge the challenged activity according to its impact on the price level. Finding no coercion of individual action, Brandeis concluded that the challenged data dissemination program merely allowed better informed individual business decision making to the benefit of society as a whole. Two years later, Justice McReynolds, for a unanimous Court, stressed even more strongly the element of coercion of individual members, in condemning an information exchange program that, in part, involved an ordinary price-fixing agreement. Id. at 83-85.

216 Id. at 82-86.

217268 U.S. 563 (1925).

218 Peritz, supra note 1 , at $87-88$. Peritz notes that when he had served a few years earlier as Attorney General, Stone had participated in initiation of the suit as a potentially good "test case." Id. at 87. 
that, notwithstanding the defendants' 70 percent share of the market, the arrangement served the public interest. Specifically, it beneficially tended to "stabilize trade and industry, to produce fairer price levels and to avoid the waste which inevitably attends the unintelligent conduct of economic enterprise," 219 by promoting more rational competitive activity.

Peritz finds that the Court's new approach to data dissemination cases established a

unified antitrust treatment of loose and tight combinations: Unless a trade association or a corporate person engaged in flagrantly anti-competitive conduct-open and obvious price control of some sort-the restraint was judged as reasonable. The new Rule of Reason, a juridical reformulation of neoclassical economics and its focus on markets rather than individual freedom of contract, embraced the logic of cooperative competition. ${ }^{220}$

3. THE CONTRASTING ANTIPATHY TOWARD LABOR ASSOCIATIONS Peritz argues that the Court's adoption of a new, postclassical Brandeisian rule of reason raised new questions about the legal treatment, respectively, of cartels, labor associations, trade associations, and trusts. Under the "classical" rule of reason announced in 1911, says Peritz, the Court had come to apply cartel doctrine to both trade and labor associations, while condemning corporations and trusts only if they acted unreasonably. The Court's acceptance of the newer version of the rule of reason by the middle of the 1920s allowed it to approve trade associations through a sympathetic examination of particular circumstances. It did not, however, lead to a similar, more receptive consideration of labor associations: "Instead, labor associations were still judged according to the classical cartel doctrine otherwise reserved for illegitimate political action. Like public price-fixing, labor union activities were illegal per se."221

\footnotetext{
219268 U.S. at 583. See Peritz, supra note 1, at 87.

220 Peritz, supra note 1 , at 88.

221 Id. at $89-90$.
} 
Peritz finds that leading lawyers, economists and federal judges perceived labor associations to be physically threatening political combinations of individuals rather than economic entities competing with employers. ${ }^{222}$ In contrast, trade associations were seen as nonpolitical, efficiency-enhancing economic organizations. Disadvantageous treatment of labor, Peritz notes, came to be justified not only on the basis of older classical conceptions, but also through the invocation of new neoclassical economic perspectives. Although it would have been eminently possible to imagine inefficiency and anticompetitive effects from both trusts and trade associations and efficiency benefits from unionization, Peritz argues, new neoclassical economic analyses attributed an intrinsic tendency to restrict competition and output only to unions. ${ }^{223}$

Peritz declares that one of the key differences between the new, market-focused neoclassical economics and older, liberty of contract based classical economics was the new economics' "horizontalization of competition."224 Citing Holmes' dissents in Vegelahn v. Guntner 225 and in Dr. Miles as representative of older conceptions, Peritz relates that Holmes, like others influenced by classical perspectives, did not distinguish vertical from horizontal aspects of economic rivalry. ${ }^{226}$ Holmes, says Peritz, thought that

222 Id. at 90-100. This view, he says, contributed, for example, to the extremely widespread granting of antilabor injunctions by federal courts during the 1920s. See id. at 94.

223 Id. at 90-100. Peritz contends that while trade associations increasingly were pictured as efficiency promoting and competition enhancing examples of new management science by Herbert Hoover and other promoters, and trusts often were declared justified by scale economies, neoclassical economists such as John B. Clark rejected claims that increased labor organization might increase labor efficiency and concluded instead that such activity only could reduce output and generate higher manufacturing costs. Id. at 95 .

224 Id. at 95.

225167 Mass. 92, 104-09, 44 N.E. 1077, 1079-82 (1896) (Holmes, J., dissenting).

226 PERITZ, supra note 1 , at 96. 
competition prevailed not only among sellers or among buyers, but also between buyers and sellers. In contrast, under the new economics,

rivalry was no longer understood as a two-dimensional process. Although horizontal rivalry among buyers or among sellers became the object of close "economic" scrutiny, vertical rivalry between buyers and sellers became a "political" question of bargaining power, of wealth distribution. Political economy was effectively partitioned into vertical and horizontal planes, into economic and political domains. ${ }^{227}$

Accordingly, wage disputes now were conceived to be a matter of wealth redistribution between classes rather than a matter of efficiency, i.e., "a question of politics rather than a question of economics." 228

In Peritz's view, this newly conceived dichotomy between horizontal economic rivalry and vertical political struggle reinforced the view of labor unions as large aggregations of individuals that not only promoted inefficiency and wealth redistribution, but also ominously threatened physical harm to persons and property. "Employers and employees did not 'compete'," Peritz notes, "they engaged in 'struggle' or 'conflict'."229 As a result, while both trade and labor associations injured the property rights of others and both were involved in rivalry, the use of physical force by government and business and the frequent issuance of injunctions were deemed justified responses to the activities of labor associations but not to the activities of trade associations. 230

227 Id. at 95.

228 Id. at 96 . Peritz stresses, however, that this was a change in analysis rather than in end result. The new economics simply used a new logic to "verif[y] the classical view of labor unions as harmful political associations." Id.

229 Id. at 97. Peritz goes on to describe how the "imaginative distinctions drawn between economic competition and political conflict," id., repeatedly were heightened by the invocation of exaggerated or baseless claims of labor violence. See id. at 97-99.

230 Id. at 97. 
4. THE DIFFERING TREATMENT OF POLITICAL AND COMMERCIAL SPEECH Peritz stresses that in the early 20th century, the Court was more receptive to government regulation of political activity than of economic behavior. This tendency was reflected, for example, in the Court's approach to free speech issues. Not only was the Court generally more sympathetic to government regulation of speech than it was to regulation of economic activity, but speech that the Court treated as economic received substantially greater judicial protection than speech that was deemed to be political. 231

Peritz stresses the severe limits of free speech doctrine prior to the landmark series of First Amendment cases appearing in 1919 that established the "clear and present danger" test for government regulation of speech. ${ }^{232}$ The Court's free speech cases after 1918 and through the 1920 s did not extend substantial new protection to political speech and did not display the same concern for tyrannical majoritarianism that was so evident in the Court's review of economic regulation. ${ }^{233}$

Union speech in particular received little protection, says Peritz, because the activities of unions, along with those of state legislatures, were categorized as falling within a political sphere distinct from the economic realm. The "verbal acts" of such "political" associations were thought to endanger private property and to pose the danger of "majoritarian tyranny." 234 On the other hand, the Court took a very different and strikingly more tolerant

231 Id. at 100-04.

$232 I d$. at 101-03. Citing the Court's 1911 decision in Gompers v. Buck's Stove \& Range Co., 221 U.S. 418 (1911), enjoining distribution of an employer's name on a "don't patronize" list, Peritz notes that prevailing doctrine equated speech with conduct, and dealt with it as a common law attempt or conspiracy to engage in banned conduct. $I d$. at 101 . As a result, says Peritz, the Court even allowed prior restraint of speech when it had a "bad tendency" to produce some harm that the state legitimately had a right to address under its police power.

$233 I d$. at 103.

234 Id. at 101. 
approach to the "verbal acts" of trade associations as those associations came to be viewed more and more as efficiency-enhancing economic organizations. The Court's 1925 opinion in Maple Flooring thus downplayed the danger of price fixing posed by the trade association activities challenged in that case and applauded the potential benefits of broader communication of market information. Peritz sees the case as an important indication that the Court in this period generally saw commercial speech as less threatening and more deserving of protection than political speech. 235

These developments in free speech case law, says Peritz, were part of a much larger contemporary transformation in cultural attitudes toward both economic and political speech. ${ }^{236}$ The unprecedented and highly successful use of mass advertising to mobilize support for America's participation in the First World War and to sell war bonds on a massive scale greatly boosted the respectability of mass advertising, which had originated in the late 19th century. After the war, proponents of mass advertising built on this new respectability and claimed that by molding public tastes such advertising could overcome the economic cycles of rising and falling demand. More broadly, advertising came to be seen as a means to foster a democratic competition of economic ideas and better informed choice by individual consumers. Advocates of mass advertising went still further and proclaimed it as the antidote to class thinking and political division and an effective promoter of Americanization through "a common culture of consumerism."237 Thus, notes Peritz, while mass advertising had a business mission, the rhetoric promoting it often was optimistically political. ${ }^{238}$
235 Id. at 102.
236 Id. at 104-06.
237 Id. at 105
238 Id. at 106. 
B. Assessing the conservative interlude between the classical rule of reason and the beginning of the New Deal

1. CONTINUITY AND CHANGE IN THE TERMS OF DEBATE At the start of Competition Policy in America 1888-1992, Peritz declares that the congressional debates preceding enactment of the Sherman Act "set the terms of debate over political economy in twentieth century America." 239 Except at a somewhat high level of generality, however, it is far from clear from Peritz's narrative that competition policy debates between 1911 and 1933 actually did proceed in the terms of debate that Peritz depicts in his discussion of the congressional deliberations and formative era case law.

Peritz stresses a number of broad continuities between developments before and after 1911. He notes that in the two decades preceding the New Deal, as in the Progressive Era, some Justices were relatively more concerned about private economic power and private restraints on competition than were other Justices. Similarly, he notes that some Justices were more wary of government economic regulation than were other members of the High Court. In addition, Peritz finds that broader political economic perspectives played an influential role in the decades following as well as preceding the Standard Oil and American Tobacco decisions. He also finds that some of the major outlooks prominent before 1911 were among the broader perspectives playing an influential role in later years.

Beyond such general parallels, however, ${ }^{240}$ Peritz's account suggests as much novelty as continuity in competition policy

$239 \quad I d$. at 5.

240 If Peritz has in mind little more than these general types of disagreements and influences in referring to the relevant "terms of debate," it seems difficult to say that they originated in the Sherman Act debates of 1888-1890. Ever since the United States was established, of course, Americans have disagreed as to the appropriate extent of government involvement in economic life and the proper balance and interrelationship between private property rights and other community concerns including the benefits attainable through competition. At the same time, broader political economic perspectives have been influential in American thinking for at least as long. If Peritz largely has in mind these kinds of general, long-recognized patterns, it is not entirely clear what is gained 
debate after 1911. Peritz does not argue that Supreme Court jurisprudence between 1911 and 1933 continued to evolve as the product of interaction between two great contending philosophical factions embracing the same divergent visions and concerns that he associates with the formative era Literalists and Rule of Reasonists. That is, he does not contend that for two decades after Standard Oil the Court was split into two major blocs, one of which was vigorously committed to unrestrained competition and strongly concerned about excessive private economic power, in contrast to a second bloc which was less strongly committed to competition, comparatively more committed to liberty of contract and private property rights, and animated heavily by a fear of social disintegration into atomistic warfare.

Indeed, Peritz does not strongly insist that the High Court after 1911 continuously was divided into two cohesive but warring camps on the basis of any other pairing of alternative, comprehensive visions of political economy either. ${ }^{241}$ Instead, he pictures a

by adopting a new terminology of competing "rhetorics" to refer to them. If, alternatively, in noting the "terms of debate" for disagreements about competition policy, Peritz means to refer to a much more specific coalescence of two sets of specific ideas and commitments along the lines he pictures in discussing early congressional and Supreme Court thinking, it becomes difficult to see strong continuity after 1911, for the reasons suggested hereafter.

241 This changed interpretative focus is reflected partly in Peritz's much less frequent invocation of the term "faction" in discussing post1911 developments as compared with earlier developments. At the same time, when he does invoke the term in connection with the later period, it is not always as clear whether he intends to refer to a grouping of Justices within a single case, a grouping based on particular core attitudes concerning competition and regulation, or a grouping of Justices according to more general conservative or liberal leanings. For example, Peritz at one point uses the term "faction" to refer specifically to the majority and dissenting groups of Justices in Tyson Bros.-United Theatre Ticket Offices, Inc. v. Banton, 273 U.S. 418 (1927). See PERITZ, supra note 1, at 74. In that case, Chief Justice Taft and Justices Sutherland, Butler, McReynolds, and Van Devanter constituted the majority that struck down the challenged price regulation, while Justices Brandeis, Holmes, Sanford, and Stone dissented. At another point, Peritz labels as a separate faction the Court majority that condemned particular data dissemination 
somewhat more complicated pattern of interaction among differing outlooks on competition, private economic power, freedom of contract, private property rights and the limits of individualistic rivalry. He finds that in certain settings and for certain Justices, older, classical commitments to deductively applied principles of freedom of contract and private property rights retained a powerful influence. In other settings or for other Justices, however, newer perspectives, including utilitarian notions of property rights and neoclassical conceptions of markets, exerted a simultaneous and at times predominant influence.

For example, Peritz contends that by 1925 the Court adopted a new Brandeisian rule of reason first announced in Board of Trade of Chicago v. United States ${ }^{242}$ to govern antitrust adjudication in place of the classical rule of reason announced in $1911 .{ }^{243}$ As already noted, Peritz sees this new version of the rule of reason as a judicial expression of neoclassical economics. 244 He does not, however, find that neoclassical perspectives entirely displaced other general political economic visions on the Court during the

arrangements in the early trade association cases. See id. at 86. In American Column \& Lumber Co. v. United States, 257 U.S. 377 (1921), this group included Chief Justice Taft and Justices Clarke, Day, McReynolds, Pitney, and Van Devanter in opposition to dissenters Holmes, Brandeis and McKenna. At a third point, Peritz declares that by 1925, when Maple Flooring Manufacturers Assn. v. United States, 268 U.S. 563 (1925), was decided, conservative and progressive factions on the Court joined together to support a lenient antitrust approach to trade association data dissemination activities. In this connection, Peritz goes on to associate Justices Sutherland and McReynolds with the conservative faction and Justices Brandeis, Holmes, and Stone with the progressive faction. See $i d$. at 81. In Maple Flooring, Justices Stone, Brandeis, Butler, Holmes, Sutherland, and Van Devanter were in the majority while Chief Justice Taft and Justices McReynolds and Sanford in fact dissented. For an indication of the Justices present on the Court when each of these cases was decided, see THE OXFORD COMPANION, supra note 124, at 985-86.

242246 U.S. 231 (1918).

243 He notes, however, that the turn to the Brandeisian rule of reason was more apparent in trade association cases than in other antitrust contexts. PERITZ, supra note 1 , at 80. 
1920 s. ${ }^{245}$ For instance, he finds that on some key antitrust issues dividing the Court in the 1920 s, conservative and progressive factions coalesced to support the same bottom line result on the basis, respectively, of either an older, classical commitment to freedom of contract and private property rights or a newer embrace of utilitarian approaches to property entitlements. ${ }^{246}$ Peritz also concludes that between 1911 and 1933, older and newer perspectives sometimes exerted an alternating influence on the thinking of individual Justices. For example, he sees a predominant influence of older, classical views in Brandeis' dissent in American Column and Lumber. ${ }^{247}$ At the same time, he finds Brandeis to have been a leading promoter of newer utilitarian property rights approaches and neoclassical perspectives in his 1918 opinions in International News Service v. Associated Press, ${ }_{2}^{248}$ and Board of Trade of Chicago v. United States. ${ }^{249}$

Peritz highlights numerous important intellectual, practical, and political changes influencing the evolution of antitrust law between Standard Oil and the start of the New Deal. His discussion appropriately and provocatively focuses attention on the relationship of antitrust developments to major contemporaneous developments in the Supreme Court's treatment of public rate regulation, labor unions, and free speech issues. Peritz's account offers a number of striking perspectives on legal developments between 1911 and 1933 and helps to further understanding of those developments as a transition between the legal and economic reasoning of the Progressive Era and that of the New Deal period.

As in other sections of his book, Peritz's discussion covers a great deal of territory and raises numerous complicated issues within the confines of a relatively brief discussion that is intended

\footnotetext{
245 See, e.g., id. at 76,81 .

246 See id. at 81.

247 See id. at 84.

248248 U.S. 215, 248-67 (1918) (Brandeis, J., dissenting). See PERITZ, supra note 1 , at 71-72.
}

249246 U.S. 231 (1918). See PERITZ, supra note 1, at 78-80, 88. 
to be only one portion of a much broader study of competition policy over the last 100 years. As already noted, this approach has substantial virtues. At the same time, it has a perhaps inevitable tendency sometimes to leave significant questions not fully explored. The following sections seek to highlight certain specific issues that seem deserving of some additional exploration, and note some specific concerns, related to a series of major topics that Peritz addresses in discussing competition policy between 1911 and 1933.

2. CONSTITUTIONAL CONSERVATISM, PUBLIC RATE REGULATION, AND THE ILLEGALITY OF CARTELS On a number of occasions, Peritz seems to overstate his case somewhat. For example, it is well known that Supreme Court conservatism reached a high point between the First World War and the New Deal. ${ }^{250}$ Nevertheless, it is not quite the case that "the Supreme Court under Chief Justices White and Taft was unrelenting in its protection of commercial activity from legislative "intervention." "251 While the Court in the 1920 s, for instance, struck down state legislation substantially more often than it had during the preceding 20 years, the Court still upheld most challenged state legislation, ${ }^{252}$ just as it had during the Progressive Era. ${ }^{253}$ Similarly, while the Court between 1911 and 1933 invalidated a number of important federal regulatory measures, ${ }_{2}^{254}$ it also rejected challenges to the constitutionality of other significant federal regulatory initiatives, even during the conservative 1920 s. ${ }^{255}$ For this and other reasons, it seems overly

250 See, e.g., KeLLY ET AL., supra note 165, at 442-53.

251 Peritz, supra note 1, at 66.

252 Kelly et AL., supra note 165, at 452.

253 See, e.g., LaWRence M. Friedman, A History of American Law 360-63 (2d ed. 1985); KeLLY ET AL., supra note 165, at 405.

254 See, e.g., Hammer v. Dagenhart, 247 U.S. 251 (1918); Bailey v. Drexel Furniture Co., 259 U.S. 20 (1922); Adkins v. Children's Hospital, 261 U.S. 525 (1923).

255 See, e.g., Stafford v. Wallace, 258 U.S. 495 (1922) (upholding the Packers and Stockyards Act of 1921); Railroad Commission of Wisconsin v. Chicago, Burlington, and Quincy Railroad Co., 257 U.S. 563 
strong to say, for instance, that the majority of Justices who voted to strike down New York legislation regulating the prices charged by theater ticket agents in Tyson Brothers-United Theatre Ticket Offices, Inc. v. Banton 256 conceived of the Constitution as "a liberal document designed solely to protect private property from political taking, a document with nothing to say about the consequences of private economic power."257

Peritz's depiction of the Court's stance toward public rate regulation and cartels in the 1920 s presents a similar problem. Peritz rightly points out that during that decade the Court established a quite narrow category of firms subject to rate regulation as "businesses affected with a public interest." He goes on to assert, however, that the Court in the 1920s declared public price regulation of companies outside this narrow category to be "illegal per se"258 along with private cartel activity.

Technically, of course, the Court declared public rate regulation of "ordinary" firms to be constitutionally invalid rather than literally illegal. The more important issue, however, is Peritz's treatment of the antitrust status of cartels in this period. The Court addressed this question most directly in the 1927 case of United States v. Trenton Potteries Co. ${ }^{259}$ Peritz pictures that decision as a landmark reiteration of what he sees as a pillar of competition

(1922) (upholding the Transportation Act of 1920 granting expanded rate regulation power to the Interstate Commerce Commission).

256273 U.S. 418 (1927).

257 PERITZ, supra note 1, at 75. All of the Justices voting in the majority in Tyson Brothers-United Theatre Ticket Offices, Inc. v. Banton who also had been on the Court in 1921 voted to approve antitrust condemnation of the collective exercise of private economic power in American Column \& Lumber Co. v. United States, 257 U.S. 377 (1921). These Justices were Chief Justice Taft and Justices McReynolds and Van Devanter. Both Taft and McReynolds also voted, in dissent, to condemn as a Sherman Act violation the trade association activity approved in Maple Flooring Manufacturers Ass'n v. United States, 268 U.S. 563, 586-87.

258 PERITZ, supra note 1 , at 72,90 . See also id. at 74.

259273 U.S. 392 (1927). 
policy since the early years of the 20th century: unanimous Supreme Court per se condemnation of private price-fixing agreements. ${ }^{260}$ Trenton Potteries, however, was not in fact a unanimous decision. Justices Butler, Sutherland, and Van Devanter all dissented while Justice Brandeis did not participate in decision of the case. ${ }^{261}$ In addition, it is far from indisputable that Justice Stone's opinion for the Court in Trenton Potteries actually "found private price-fixing illegal regardless of intent and competitive effect."262

3. THE NATURE AND GROWING INFLUENCE OF NEOCLASSICAL ECONOMICS A major focus of Peritz's discussion of the 1911 to 1933 period is the growing influence within antitrust law of broad developing changes in economic theory. Peritz argues that new neoclassical economic perspectives based on a functional examination of markets instead of a deductive application of freedom of contract principles ${ }^{263}$ played an influential role in Supreme Court jurisprudence as early as the Court's 1920 opinion in United States v. U.S. Steel Corp. ${ }^{264} \mathrm{He}$ also declares that neoclassical economic perspectives informed the new Brandeisian rule of reason that he finds the Court adopted in antitrust cases by 1925 in place of the older classical rule of reason established in 1911.265

Peritz's brief discussion of the nature of early 20th-century neoclassical economics leaves open a series of questions that

260 See PERITZ, supra note 1 , at 73 (referring to the "Court's unanimous decision in Trenton Potteries").

261 See 273 U.S. at 407.

262 PERITZ, supra note 1 , at 73. Specifically, the case can be read narrowly to establish an approach applicable only when the cartel participants enjoy a large collective share of the market in which they operate. See 273 U.S. at 394, 396, 398. Peritz acknowledges this in his earlier writing but omits mention of it in his new book. For his earlier mention of this alternative reading of the case and its relevance for a per se characterization of the opinion, see Peritz, Counter-History, supra note 4, at 287 n.94.

263 See PERITz, supra note 1 , at $79,88$.

264251 U.S. 417 (1920). See PERITZ, supra note 1, at 67.

265 See PERITZ, supra note 1 , at $78-80,88$. 
profitably might be explored at greater length. For example, in practice, how thoroughly and radically did the thinking of persons associated with early 20th-century American neoclassical economics actually depart from more traditional economic perspectives? To what extent and in what ways did early academic or popular variants of "neoclassical" thinking in early 20th-century America incorporate various major aspects of earlier economic thinking within their own analyses, even while moving beyond them in other respects?

Second, when is it safe to conclude that a particular Supreme Court opinion reveals its author's knowledge and acceptance of neoclassical economics? For instance, how compelling is it to infer, as Peritz at times does, that if a given Supreme Court opinion after the First World War focused on market conduct and effects rather than stressing general freedom of contract rhetoric, the Justice writing the opinion must have embraced neoclassical rather than classical economic perspectives? ${ }^{266}$

266 See, e.g., id. at 67, 79 (asserting a neoclassical economic basis for Justice McKenna's opinion in U.S. Steel); 88 (declaring that the new Brandeisian rule of reason first announced in Board of Trade of Chicago $\nu$. United States (1918) was "a juridical reformulation of neoclassical economics and its focus on markets rather than individual freedom of contract"). The fact that a particular focus may have been consistent with a neoclassical outlook, of course, does not necessarily mean that it might not also have been adopted by someone with a more traditional general economic orientation. Persons with a "pre-neoclassical" outlook as well as those thoroughly imbued with neoclassical perspectives thought it sometimes was important to consider the actual effects of particular conduct and the dynamics of particular markets. It would seem difficult for Peritz to argue that the absence of an explicitly articulated emphasis on freedom of contract principles indicates the abandonment of a firm commitment to them. In his discussion of the congressional debates preceding passage of the Sherman Act, for example, Peritz argues that one of two great congressional factions dominating the debates embraced a central commitment to such principles in contrast to the opposing faction's central commitment to full and free competition, even though he finds no instances in which members of the former "faction" actually ever invoked general freedom of contract principles explicitly. See id., at 18. 
Third, how clearly does the Court's opinion in U.S. Steel reflect not only the influence but also the inadequacies of neoclassical analyses of concentrated markets? Peritz notes that Justice McKenna's opinion for the Court in U.S. Steel required a showing of a very high market share to establish a completed offense of monopolization under section 2 of the Sherman Act. ${ }^{267}$ Peritz associates this stance with neoclassical economic thought, in which, he says, "markets were understood categorically as either competitive or monopolistic. . . . [A]nything short of complete market control was treated as competitive."268 Did economists such as John B. Clark literally believe that any markets not occupied entirely by a single firm with 100 percent of the trade, but instead dominated, for example, by a firm enjoying merely a 90 or 95 percent market share should be deemed functionally equivalent to a market involving atomistic competition among a hundred small sellers? The strength of this claim might be furthered considerably if Peritz cited at least one piece of early neoclassical writing that directly articulated such a position.

4. THE LOGIC OF THE CONTRASTING TREATMENT OF TRADE AND LABOR ASsOCIATIONS Another central theme in Peritz's discussion of the period between 1911 and 1933 is the Supreme Court's sharply contrasting treatment of trade and labor associations. As Peritz notes, the Court issued a series of decisions in the 1920s that strongly restricted the scope of labor union activity. After 1925, however, the Court displayed a much more tolerant attitude toward trade association activity of the sort challenged in Maple Flooring Manufacturers Association v. United States. ${ }^{269}$ Peritz sees such differing treatment as a central aspect of competition policy between the First World War and the New Deal; and he persuasively argues that general political concerns and values strongly influenced its development.

Peritz relates the Court's approach not only to specific political value preferences, but also to more general ongoing changes

267 See id., at 67.

$268 I d$.

269268 U.S. 563 (1925). 
in intellectual thought. He suggests that "[i]t seems logical to have anticipated that, like trade associations, labor associations would be judged more leniently under the new Rule of Reason, because they would be viewed as economic activities in the private domain."270 Peritz finds, however, that "elite lawyers and economists, federal judges and Republican administrations" were able to justify an opposite result. They did so, he says, by adopting "a common imaginative framework" that treated labor unions as physically threatening political factions rather than as economic organizations competing with employers. ${ }^{271}$

Peritz's view raises, among other issues, a question as to why any new intellectual outlook was needed to justify differing treatment for trade and labor associations. To what extent did sympathy for trade association data dissemination in fact logically call into question continued hostility to union activities in pursuit of higher wages? Was the Court's less sympathetic treatment of union efforts as compared with trade association activities so inherently inconsistent with previously prevailing economic logic that it necessitated the development of a new "imaginative framework"? Granted that the Court's treatment of labor and trade associations was strikingly inconsistent in spirit and that conservative political leanings largely accounted for the difference, was there really not enough flexibility in the old imaginative framework to permit "logical" justification of the Court's approach?

Traditional observers already perceived various forms of cooperative activity as beneficial behavior distinguishable from naked cartel activity. Approval of particular, newly prominent forms of collective activity alongside condemnation of other conduct would seem readily possible within a traditional, pre-neoclassical frame of reference, as long as one was willing to conclude that the condemned conduct was the equivalent of harmful cartel activity while the approved behavior was not. It was not difficult for conservative observers either in the 1920 s or earlier to adopt exactly

270 PERITZ, supra note 1 , at 89.

271 Id. at 90. 
this approach to condemn union efforts in pursuit of higher wages while approving trade association data dissemination schemes, at least when such schemes were found not to involve any collective agreement to raise prices or reduce output.

5. PERCEPTIONS OF LABOR UNIONS AS THREATENING POLITICAL ORGANIZATIONS SHARPLY DISTINGUISHABLE FROM ECONOMICALLY EFFICIENT TRADE ASSOCIATIONS Whether or not it was logically necessary, did key actors in the 1920s in fact adopt a new "imaginative framework" justifying harsh treatment of labor unions alongside lenient treatment of trade associations? Peritz insists that they did. Specifically, he asserts that Supreme Court Justices and others in the 1920s embraced a new intellectual framework in which collective labor efforts to obtain higher wages were believed to raise political but not economic issues. In making this argument, he points to three conceptual developments fostering an image of labor associations as dangerous political organizations sharply distinguishable from trade associations. In particular, he stresses: ongoing characterizations of organized labor as physically threatening to persons and property; new, "horizontalized" conceptions of competition within neoclassical economics; and the Supreme Court's selective application of classical cartel doctrine in the 1920s.

Peritz's portrayal of the ongoing influence of the first of these factors is persuasive. The impact of the second two factors seems less certain, however, for the following reasons.

a. The neoclassical "horizontalization" of competition As already noted, Peritz connects the disparate treatment of labor and trade associations in the 1920 s to what he sees as a fundamental difference between classical and neoclassical economics. $\mathrm{He}$ argues that with the rise of neoclassical economics, an older, undifferentiatedly two-dimensional conception of competition became "horizontalized." In consequence, he contends, labor efforts to secure higher wages came to be viewed as vertical, political conduct rather than horizontal, economic activity. 272

272 See id. at 95-96. 
In making this point, Peritz reiterates a characterization of 19th-century economic thinking that he briefly also asserts in discussing Progressive Era antitrust jurisprudence. In analyzing the early railroad cartel cases, for example, Peritz contends that "classical political economy made no distinction between horizontal and vertical dimensions. Competition was understood as both vertical and horizontal, as involving rivalry not only among sellers but also between buyers and sellers."273 Similarly, in discussing the Court's 1911 resale price maintenance decision in Dr. Miles Medical Co. v. John D. Park \& Sons Co., ${ }^{274}$ Peritz notes that

In more recent times, we have tended to think of competition only as a horizontal phenomenon and hence we separate commercial conduct into horizontal and vertical dimensions. Classical economics, however, made no such distinction. Competition was understood as entailing rivalry not only between two patent medicine makers (horizontal) but also between a manufacturer and its retailers (vertical). In consequence, no one on the Court blinked at citing the cartel cases as precedent. 275

Did 19th- and early 20th-century classical economic thinkers really make "no distinction" between horizontal and vertical rivalry? Did neoclassical economic analysts in the 1920 s really come to see efforts to secure higher wages "as a question of politics rather than a question of economics"? ?76

The answer to both questions would appear to be no.

It is true that in some 19th-century classical economic writing, "competition" was used to refer partly or even primarily to vertical relationships, especially the relations between employers and employees. 277 Thus, for example, Amasa Walker declared that labor and capital are "competitors" and that the "competition of

\footnotetext{
$273 \quad$ Id. at 34.

274220 U.S. 373 (1911).

275 PeRITZ, supra note 1 , at 54.

$276 \quad I d$. at 96.

277 See, e.g., Herbert Hovenkamp, Labor Conspiracies in American Law, 1880-1930, 66 TEx. L. REv. 919, 936 (1988).
} 
labor and capital never ceases; but it respects the bond of union in which only each has its own full development."278 In general, however, when classical economic writers described a natural economic world of unimpeded production and exhange in which the disparate interests of consumers, capital, and labor all were coordinated and ultimately harmonized through the operation of the powerful and pervasive natural law of competition, they not only distinguished between vertical and horizontal rivalry, but stressed primarily the latter. At the heart of their thinking was the faith that, as long as individuals were not impeded in their free pursuit of economic opportunity, abnormally high prices and returns temporarily prevailing in any particular market would attract new entrants. Such new entry, they believed, would expand available supply, intensify competition among sellers, and force prices downward until supply and demand once again naturally achieved an equilibrium generating fair, normal prices and returns. ${ }^{279}$

Francis Bowen, for example, explained that

if the gains in one department of enterprise are notoriously above the average,-if it is even suspected by a multitude of sharp-sighted observers, who are on the lookout for such opportunities, that they exceed the average,-more capital is at once attracted into the employment, till, by the competition of the capitalists with each other, the rate of Profit is reduced to the common standard in other enterprises. 280

Similarly, Simon Newcomb declared that "If the makers [of an article] charge too much for it, other makers will compete and thus lower the price."281 In the same vein, Henry Wood declared

278 Amasa Walker, The Science of Wealth: A Manual of Political Economy. Embracing the Laws of Trade, Currency, and Finance 21 (7th ed. 1874).

279 For an extended discussion of classical economic thinking and its relationship to political liberalism, laissez-faire constitutionalism, and early antitrust law, see May, supra note 54, at 262-309.

280 Francis Bowen, The Principles of Polttical Economy Applied to the Condition, the Resources, and the Institutions of the AmERican People 241 (3d ed. 1863) (emphasis added).

281 Simon Newcomb, Principles of Political Economy 448 (1886). 
that competition in the business world consisted "either in giving a better article at the same price, or as good a one for less." 282

Indeed, the perceived importance of horizontal competition, understood to be distinct in nature and importance from vertical rivalry despite the fact that such rivalry also at times was referred to as a form of "competition," led at least one leading late 19thcentury writer to stress the horizontal rather than vertical character of competition in the specific context of relations between labor and capital. Thus, Julian M. Sturtevant emphasized that "It should . . . be borne in mind, that the competition that determines wages . . . is the competition of labor with labor, and not of labor with capital."283

In concluding that classical economics did not distinguish between vertical and horizontal dimensions of economic rivalry, Peritz cites almost no writing by classical economists themselves. ${ }^{284}$ Instead, he primarily relies on Holmes' dissenting opinions in Dr. Miles and in the earlier Massachusetts high court case of Vegelahn v. Guntner. 285 It seems somewhat ironic, however, to rely on those dissenting opinions to demonstrate that orthodox thought failed to distinguish between horizontal and vertical economic rivalry. In his famous 1896 dissent in Vegelahn v. Guntner, Holmes explicitly acknowledged the long-standing policy in favor of horizontal business competition. ${ }^{286} \mathrm{He}$ went on to concede that

282 Henry Wood, The Political Economy of Natural Law 36 (1894).

283 Julian M. StuRTEVANT, ECONOMics OR THE SCIENCE OF WeALTH 158 (1877) (emphasis in original).

284 The only passage from classical economic writing that he quotes to support his conclusion that classical economists made no distinction between vertical and horizontal rivalry is a statement from Francis Walker's Political Economy defining competition as "the operation of individual self-interest, among buyers and sellers." See PERITZ, supra note 1, at 34 (quoting Francis A. Walker, PoltTiCal ECONOMY 262 (3d ed. 1888)).

285167 Mass. 92, 104-09, 44 N.E. 1077, 1079-82 (1896) (Holmes, J., dissenting).

286167 Mass. at 106-07, 44 N.E. at 1080-81 (Holmes, J., dissenting). 
some people believed that the vertical rivalry between employers and workers could not similarly be deemed "competition." Precisely for this reason he suggested that such vertical rivalry might be referred to as the "free struggle for life" rather than "free competition."287 In his dissent in Dr. Miles, Holmes did use the phrase "the competition of conflicting desires" in arguing that prices produced by even a monopolist should be deemed to be fair because they represented an equilibrium point between the wishes of the seller and those of the buyers. ${ }^{288}$ In doing so, however, Holmes expressly acknowledged the unorthodoxy of his own thinking on competition and noted the more conventional, horizontallyfocused meaning of "competition" embraced by his colleagues on the bench. 289

287167 Mass. at 107, 44 N.E. at 1081 (Holmes, J., dissenting).

288220 U.S. 373, 412 (Holmes, J., dissenting).

289 Holmes declared: "I am in the minority as to larger issues than are concerned here. I think that we greatly exaggerate the value and importance to the public of competition in the production or distribution of an article . . . as fixing a fair price." 220 U.S. at 411-12 (Holmes, J., dissenting). As noted previously, Peritz also points to the majority opinion in Dr. Miles as confirmation of his view of classical conceptions of competition. Peritz sees $D r$. Miles as a case in which the majority condemned resale price maintenance agreements per se in substantial part because the Court already had established such treatment for cartels and was influenced by classical economic thought to see no difference between horizontal and vertical dimensions of rivalry. See PERITZ, supra note 1, at 54. This would be a stronger argument if the Court had expressed objection to resale price maintenance because of its effect in dimming rivalry or "competition" between the manufacturer and its affected dealers. In actuality, however, the Court repeatedly declared that its main reason for condemning the system of resale price maintenance contracts involved in the case was that the contracts would have the same effect as a cartel among the dealers, the most classic of restraints on horizontal competition. It therefore seems hard to read the case as a strong general expression of equal concern for diminished rivalry between a seller and buyers, on the one hand, and among sellers on the same level in a chain of distribution, on the other. For a more extended discussion of Dr. Miles, relating the opinion to the broader context of contemporary political and economic thought and suggesting possible problems with reading the case to establish a rule of per se illegality for resale price maintenance agreements, see May, supra note 54, at 389-91. 
While Peritz underemphasizes classical distinctions between horizontal and vertical rivalry, he simultaneously overemphasizes the contrast between horizontal and vertical in neoclassical economics. Peritz notes that between 1911 and 1933, neoclassical economists saw unions as anticompetitive combinations whose activities increased wages and reduced output. He goes on to declare, however, that within neoclassical economics "vertical rivalry between buyers and sellers became a 'political' question of bargaining power, of wealth distribution."290 Peritz does not simply assert that vertical rivalry between employers and employees was perceived to have strong political as well as economic overtones. Instead, he declares more strongly that with the coming of neoclassical economics, "[p]olitical economy was effectively partitioned into vertical and horizontal planes, into economic and political domains." 291 As a result, he says, battles over wages came to be viewed as "a question of redistributing wealth between classes rather than a question of efficiency, as a question of politics rather than a question of economics." 292

It is true that 20th-century neoclassical economics strongly has sought to limit its focus to issues of efficiency and to avoid normative judgments about the distribution of wealth. This, however, does not mean that interactions between buyers and sellers or the vertical impact of market power exercised by actors at any particular level in a distribution chain ever ceased to be seen as phenomena still very much within the economic realm and important continuing objects of economic analysis.

Peritz declares that the interplay of the conflicting desires of buyers and sellers in the labor context was no longer seen as "a question of economics" because neoclassical economics deemed vertical rivalry to raise issues of wealth distribution falling within the political rather than economic domain. Resolution of the conflicting desires of buyers and sellers, whether in business or labor contexts, of course, does have distributional

\footnotetext{
290 PeRITZ, supra note 1, at 95.

291 Id.

Id. at 96.
} 
consequences. Collective efforts either by laborers or by the sellers of various commodities may well force affected buyers to pay more than they otherwise would for labor services or goods. Such effects certainly can be assessed in terms of their perceived "political" desirability. At the same time, however, such vertical interactions and effects have efficiency implications as well. The fact that neoclassical economists have stressed the efficiency rather than distributional consequences of lessened supply and higher prices resulting from the collective activity of sellers of either labor services or goods does not indicate that they thereby have limited themselves to concern for effects and activity confined to a "horizontal plane" or that they have treated interlevel interaction and effects as falling exclusively into a political realm outside the borders of their own field.

b. The selective application of classical cartel doctrine Peritz suggests that a political characterization of labor associations, in contrast with the economic conceptualization of trade associations, was furthered significantly by the Supreme Court's selective application of cartel doctrine in the 1920s. He notes that while the Court earlier had applied "classical cartel doctrine" to declare "both labor and trade associations illegal per se,"293 the Court by the middle of the 1920s no longer applied this doctrine to trade associations, even though it did continue to apply it to organized labor. This does not lead Peritz simply to conclude that for antitrust purposes union activities still were treated as dangerous economic behavior analogous to cartels among rival businesses. Instead, Peritz strongly associates "classical cartel doctrine" in the 1920 s with the political realm. He declares that by the middle of the 1920 s, the Court had decided that labor, but not trade, organizations "would be viewed under the classical Rule of Reason, its liberty of contract logic, and its common-law cartel doctrine otherwise reserved for state price-fixing." 294 As a

\section{Id. at 92.}

294 Id. at 93 . See also id. at 90 (similarly noting that "labor associations were still judged according to the classical cartel doctrine otherwise reserved for illegitimate political action"). 
result, he says, "[1]ike public price-fixing, labor union activities were illegal per se."295

Peritz's argument again seems a bit too sharply drawn. For example, despite its markedly conservative leanings, the Court never treated labor associations as "illegal per se," either in the 1920 s or in the preceding decades. The Court also never condemned all collective activities undertaken by unions to raise wages or improve working conditions, ${ }^{296}$ even though it did greatly restrict the range of tactics left open to organized labor during the 1920s. ${ }^{297}$ In addition, when the Court condemned particular tactics on the part of organized labor, the Court's opinions did not compare such tactics to illegitimate government rate regulation, but did at times explicitly analogize them to private business conduct that previously had been found to violate the Sherman Act. ${ }^{298}$

6. POLITICAL AND ECONOMIC SPEECH Peritz concludes his examination of the 1920 s by connecting the political conceptions of unions that he finds to have been prevalent in that decade to the broader developing pattern of First Amendment law. He persuasively notes that contemporary beliefs that labor strikes and

295 Id. at 90.

296 For example, writing for the Court in American Steel Foundries v. Tri-City Central Trades Council, 257 U.S. 184 (1921), Chief Justice Taft affirmed, in speaking of collective efforts to withhold labor in order to secure higher wages, that "[t]he right to combine for such a lawful purpose has in many years not been denied by any court. The strike became a lawful instrument in a lawful economic struggle or competition between employer and employees as to the share or division between them of the joint product of labor and capital." Id. at 209.

297 See, e.g., KeLly ET AL., supra note 165, at 449-50.

298 See, e.g., Duplex Printing Press Co. v. Deering, 254 U.S. 443, 467 (1921); Bedford Cut Stone Company v. Journeymen Stone Cutters' Association of North America, 274 U.S. 37, 54 (1927). In both of these cases, the Court relied on Eastern States Retail Lumber Dealers' Association v. United States, 234 U.S. 600 (1914), which had condemned under the Sherman Act a boycott by retailers against wholesale suppliers who also made retail sales. 
boycotts were more dangererous than trade association information exchange programs led to markedly different treatment of labor and trade associations in First Amendment as well as antitrust contexts. In addition, Peritz thoughtfully relates this pattern to other major developments concerning commercial and political speech between 1911 and 1933. As already noted, he particularly highlights the rise and expanding application of mass advertising and the changing cultural justifications for it. This illuminating analysis leads directly into Peritz's introductory discussion of several key intellectual developments that helped to usher in the dramatic changes in political economic thought, government regulation, and legal doctrine occurring in the 1930s.

IV. The bridge to postclassical economics, the New Deal, and modern political economy: Chamberlin, Schumpeter, and Berle and Means on the new economy and the modern corporation

Peritz finds that despite its substantial influence during the 1920 s, neoclassical economics failed to provide an explanation for the rise of mass advertising and the activities of trade associations. Neoclassical premises, he points out, conflicted with the advertising faith that consumers were influenced by more than just price in deciding what to buy. In addition, the systematic cooperative activities of trade associations appeared to violate neoclassical theory's "exclusive logic of competition." 299 The new pervasiveness of concentrated markets, moreover, belied the neoclassical assumption of a world in which markets either were purely competitive or were dominated by a single monopolist.

Peritz notes, however, that in the wake of the Great Crash of 1929, two new "paradigm-shattering books" appeared that would fundamentally reshape discourse about economics and competition policy for decades to come. ${ }^{300}$ These two books were: Adolf Berle and Gardiner Means' 1932 classic, The Modern

299 PERITZ, supra note 1 , at 106.

$300 \quad I d$. at 107. 
Corporation and Private Property, and Edward H. Chamberlin's 1933 book, The Theory of Monopolistic Competition.

The latter book, notes Peritz, provided powerful new general explanations for the dynamics of the real-world markets that neoclassical economics had failed to explain:

Chamberlin's oligopoly theory introduced an economic logic of cooperation to explain the lack of price competition in industries with few firms as well as those with trade associations-that is, industries organized to act as though they were oligopolies. His theory of monopolistic competition introduced a new economic logic of rivalry to explain mass advertising and, more generally, the alternatives to price competition in industries with many firms. ${ }^{301}$

While Chamberlin, however, decried the proliferation of monopolistic competition by way of product advertising, finding much of it to be mere "useless differentiation," his Harvard mentor Joseph A. Schumpeter 9 years later, in Capitalism, Socialism and Democracy, would herald the proliferation of products as simply one part of the constant process of innovation, the "perennial gale of creative destruction," that constantly undercut monopoly and kept capitalism vital. ${ }^{302}$

Peritz notes that the year before Chamberlin's book appeared, Berle and Means published their own revolutionary and highly influential departure from neoclassical analysis, The Modern Corporation and Private Property. Peritz stresses that Berle and Means did not simply conclude that ownership had come to be separated from control in the large modern corporation. They also found, he says, that the cooperative dynamics of modern concentrated industries had in a great many instances replaced the vigorous marketplace competition that otherwise might have pushed managers effectively to maximize corporate returns. In addition, Peritz relates, Berle and Means emphasized the nature of the modern corporation as a complex web of public interests and private rights that appropriately should be administered by a "neutral technocracy" of industrial and social engineers. This last empha-

301 Id. at 108.

302 See id. at 109. 
sis, notes Peritz, provided a strong theoretical foundation for the legislative initiatives of the early New Deal.

Peritz believes the appearance of these new works constituted a major watershed in 20th-century approaches to competition policy: "The discourse of postclassical economics, with eye-opening concepts such as oligopoly, monopolistic competition, innovation, and corporate control, not only unlocked a rhetorical gateway to the New Deal but also expanded the boundaries of modern competition policy for the remainder of the century." 303 V. Conclusion: the strengths and limits of a rhetorical
history of competition policy in America

The remaining two-thirds of Competition Policy in America 1888-1992 explores developments during the six decades after Chamberlin and Berle and Means published their pathbreaking books. In these later chapters, Peritz takes note of a great many specific changes over time in the economic, political, social, theoretical, and polemical contexts within which competition policy evolved.

Notwithstanding such changes, Peritz ultimately concludes that competition policy from the New Deal to the 1990s fundamentally continued to be shaped by interaction between the same two "twin rhetorics of free competition," the same two "clusters of images and arguments," 304 that he believes dominated competition policy development from 1888 to 1933 . Both before the New Deal and ever since, says Peritz, one of these two profoundly influential rhetorics continually has embraced a primary ethical commitment to individual liberty and heavily has emphasized freedom from government power. Simultaneously, Peritz believes, the other influential rhetoric continually has embraced a primary ethical commitment to rough equality and has placed comparatively greater emphasis on competition freed from inordinate private economic power. ${ }^{305}$

$\begin{array}{ll}303 & \text { Id. at } 110 . \\ 304 & I d . \text { at } 301 . \\ 305 & I d .\end{array}$


The sections of Competition Policy in America 1888-1992 that focus on the decades from the passage of the Sherman Act to the start of the New Deal provide an important part of the foundation for this new interpretation of competition policy as a whole since the $1880 \mathrm{~s}$. For the reasons already noted, some of Peritz's major conclusions in these sections seem distinctly more convincing than do others. Partly, this is due simply to the fact that the book's sweeping coverage necessitated relatively compact treatments of some very complex topics that did not permit all significant questions to be explored at length. More fundamentally, however, Peritz's thoroughgoing depiction of competition policy as the product of ongoing interaction between the two twin "rhetorics" just noted repeatedly appears to be contradicted, sometimes rather sharply, by prominent aspects of the historical record. Notwithstanding these limitations, however, Competition Policy in America 1888-1992 is an important contribution.

Peritz's basic interpretative approach is a form of structuralist intellectual history. While such an approach has been relatively rare in writing on antitrust history, this variety of intellectual history has been the focus of considerable scholarly attention over the last 25 years in connection with other major historical issues. ${ }^{306}$ Indeed, the scholarly literature consisting of works either seeking to pursue such an approach or critiquing it has become quite voluminous in recent years, even as the specific varieties of strongly or softly "structuralist" approaches have proliferated.

Peritz characterizes his own work as primarily an adaptation and application of the work of Michel Foucault. ${ }^{307} \mathrm{He}$ also notes a general connection, however, between his own work and the great outpouring of recent "rhetorical history" addressing republicanism and liberalism in many periods and phases of American life. ${ }^{308}$ In the latter setting, scholars have devoted particularly great attention over the last several years to the possibilities and limitations of "rhetorical history" in general.

306 See, e.g., Rodgers, supra note 191.

307 See PERITZ, supra note 1, at 306 n.7.

Id. 
Within that literature, for example, scholars have engaged in intensive debates about the meaning of and possible differences among, "paradigms," "ideologies," "languages" and "rhetorics" and have disagreed as to which, if any of these should be embraced as an appropriate interpretative emphasis in various specific contexts or in general. ${ }^{309}$ Recent writing has suggested not only benefits but also potential difficulties in perceiving of intellectual thought in terms of rhetorics or languages of discourse. A number of scholars, for instance, have expressed doubts as to how sharply "republicanism" and "liberalism" can be separated from one another as influential general perspectives. Questions also have been raised as to whether the thought of particular individuals involved in important historical struggles such as the 1787-1788 debates over constitutional ratification plausibly can be understood as reflecting one and only one of these two bodies of thought or of speech. ${ }^{310}$ In addition, some scholars have argued recently that still other general rhetorics or ideologies played an influential role in important periods of American history along with republicanism and liberalism. ${ }^{311}$ At the same time, however, other writers have expressed basic reservations about interpreting intellectual thought strongly in terms of paradigmatic rhetorics, no matter how numerous. A growing number of historians, for example, have stressed that the categories of "republicanism" and "liberalism" are constructs developed by modern historians rather than discrete languages that individual historical actors ever spoke in exclusively or, indeed, even recognized to have a separate existence. 312

309 See Rodgers, supra note 191, at 21-22.

310 See, e.g., Lance Banning, Jeffersonian Ideology Revisited: Liberal and Classical Ideas in the New American Republic, 43 WILLIAM \& MARY Q. 3, 12 (1986); James Kloppenberg, The Virtues of Liberalism: Christianity, Republicanism, and Ethics in Early American Political Discourse, 74 J. AM. HIST. 20 (1987); Rodgers, supra note 191, at 35.

311 See, e.g., KRAMNICK, supra note 191, at 260-88.

312 See, e.g., Rodgers, supra note 191, at 36-37; Wood, supra note 191 , at 158 . 
Peritz's work connects the highly important realm of American competition policy since the late 1880 s to this rich current of recent scholarship on American intellectual thought. In so doing, his work opens up a substantial range of methodological as well as substantive issues for productive, ongoing exploration for a long time to come.

Would it have been possible for Peritz or anyone else to write a rhetorical history of the last 100 years of competition policy that did not generate scholarly disagreements or questions about possible oversimplification? The experience of the last 25 years of scholarly writing on intellectual history suggests very strongly that the answer to this question is no.

This does not mean that this type of approach to historical interpretation is not valuable. Quite the opposite is true. It is, however, in the nature of even the very best of such "structuralist" histories that they tend to promote vigorous scholarly debate and discussion about important aspects of American experience. Peritz's prodigious, densely packed, and sweeping new study makes precisely such a contribution while simultaneously offering a host of valuable, specific insights concerning the history of competition policy in America over the last hundred years.

No one else, indeed, has even attempted to create what Peritz has written, an interpretative history of the entire, long story of competition policy since the 1880 s, focusing not only on antitrust law but on constitutional law, labor law, corporate law, First Amendment jurisprudence, and other substantive areas within an ever changing political, economic, and theoretical context. Peritz's effort is formidable and his approach continually innovative. His sometimes disputable but invariably thought-provoking book is one that should be read and considered energetically by anyone interested either in the long-run story of competition policy in America or in the history of American law more generally from the late 19 th century to the present. 